\title{
An overview on the biology and phylogeny of the early-diverging oomycetes
}

\author{
Anthony T. Buaya ${ }^{1.2^{*}}$ and Marco Thines ${ }^{1,2}$
}

\begin{abstract}
Holocarpic oomycetes are ubiquitous especially in marine and freshwater environments. These organisms are mostly obligate biotrophic parasites and members of the deep-branching, early-diverging clades of the Oomycota, comprising of several genera that had their phylogenetic position only recently investigated (Miracula, Olpidiopsis, Eurychasma, Haptoglossa, Anisolpidium, Diatomophthora, Pontisma, Haliphthoros) as well as some unresolved genera (Ducellieria, Petersenia, Sirolpidium, Eurychasmidium, Pseudosphaerita, Rozellopsis). Despite their widespread occurrence and importance for understanding the evolution of the oomycetes, knowledge on the biology and ecology of these bizarre organisms is still fragmentary for temperate regions and almost absent for the tropics. Here, an overview on the current state of knowledge on early-diverging oomycetes is presented, with emphasis on the general biology, systematics and ecology.
\end{abstract}

Keywords: early-diverging clades, Oomycetes, Oomycota, phylogeny, systematics

\section{Oomycetes}

The oomycetes are fungal-like heterotrophic organisms belonging to the Kingdom Straminipila (often informally referred to as "stramenopiles") of the SAR (Straminipila, Alveolata, Rhizaria) Superkingdom (Baldauf et al., 2000) together with phototrophic organisms, such as the brown seaweeds and diatoms (Silberfeld et al., 2014). Sometimes, the kingdom Straminipila is also referred to as Chromista or Chromalveolata (Cavalier-Smith and Chao 2006; CavalierSmith 2018), but as the older kingdom concept 'Chromista' is not monophyletic and as the Alveolata and Straminipila are both very deeply branching lineages, 'Straminipila' is the preferred kingdom-level designation. The Oomycota are sometimes referred to as Pseudofungi (Cavalier-Smith 1997; CavalierSmith and Chao 2006) but then also including the Hyphochytriomycota and Labyrinthulomycota. As the latter two groups are often described under the zoological, rather than the

${ }^{1}$ Goethe Universität Frankfurt am Main, Department of Biological Sciences, Institute of Ecology, Evolution and Diversity, Max-von-Laue Strasse 13, D-60438 Frankfurt am Main,Germany

${ }^{2}$ Senckenberg Biodiversity and Climate Research Centre, Senckenberganlage 25, D-60325 Frankfurt am Main, Germany

*Corresponding email: anthony.buaya@senckenberg.de

Date Submitted: 11 November 2019

Date Accepted: 27 May 2020 botanical Code of Nomenclature and some bacteriophagic unicellular protists seem to branch within the group (Tong 1995; Kühn et al., 2004), the phylum designation as Oomycota is preferable. The group is traditionally studied by mycologists, because of superficial similarities due to convergent evolution (Alexopoulos et al., 1996; Lévesque 2011). However, there is no immediate phylogenetic relationship with the Mycota (Alexopoulos et al., 1996; Beakes, Glockling and Sekimoto 2012; Beakes and Thines 2017). Several characters set oomycetes apart from Mycota. Asexual reproduction is by means of conidiosporangia or zoosporangia, which often produce heterokont, often kidney or bean shaped zoospores with a posteriorly directed whiplash flagellum and an anteriorly directed tinsel flagellum that is ornamented with tripartite mastigonemes. The flagella are usually subapically or laterally inserted in a groove. Many species, predominantly in the Saprolegniomycetes, produce two morphologically distinct generations of zoospores - primary zoospores that are weak swimmers and often pyriform in shape, and secondary zoospores, which are reniform in shape and efficient swimmers. The reason for this diplanetism is not well understood (Dick 2001; Walker and van West 2007). The cell wall of oomycetes is composed primarily of $(1,3)$ and $(1,3 ; 1,6) \beta$-glucans and varying amounts of cellulose rather than chitin (Cooper and Aronson 1967; Bartnicki-Garcia 1968; Lin and Aronson 1970; Wang and Bartnicki-Garcia 1974; Myklestad and Granum 2009); cytoplasmic dense-body or "finger-print" vacuoles with storage of mycolaminarin polysaccharide phosphate (Traquair 
and McKeen 1980; Bortnick et al., 1985; Beakes et al., 2012); mitochondria with tubular cristae (Alexopoulos et al., 1996; Beakes et al., 2012) and a different biochemical pathway for the synthesis of amino acid lysine (Vogel 1960, 1961, 1964).

The Oomycota are ubiquitous and can be found in almost all types of environments, in both aquatic (lakes, rivers, ponds, mangrove swamps, brackish waters, oceans, arctic, Antarctica) and terrestrial ecosystems (soil, muds, plant parasites) (Sparrow 1960; Dick 2001; Beakes et al., 2012; Thines 2014; Beakes and Thines 2017). In aquatic environments, most of the known species were recorded from freshwater, living as saprotrophs or parasites of algae and animals (Sparrow 1960; Marano et al., 2016). Only a few species are known from the marine realm, mostly living as obligate biotrophic parasites (Sparrow 1960), saprophytes in coastal environments (e.g. Halophytophthora, Salisapilia) (Hulvey et al., 2010; Marano et al., 2016), and others life as facultative anaerobic saprophytes in anoxic water bodies (e.g. stagnant ponds, heavily polluted waters) (Emerson and Weston 1967; Emerson and Held 1969; Alabi 1972; Emerson and Natvig 1981). Most of the known terrestrial forms are primarily facultative and obligate biotrophic parasites of many vascular plants in natural and managed ecosystems, which cause devastating outbreaks on several agriculturally and horticulturally important crops (Thines 2014).

To date, the Oomycota comprise about 1,700 described species that have been grouped into about 100 genera (Beakes and Thines 2017; Wijayawardene et al., 2020). The phylum contains two major classes, Saprolegniomycetes (Thines et al., 2015) and Peronosporomycetes (Dick 2001), as well as several early-diverging lineages (Eurychasmatales, Haliphthorales, Haptoglossales, Miraculales, Olpidiopsidales, Pontismatales) that are mostly holocarpic marine obligate biotrophic parasites with unresolved phylogenetic relationships to each other (Sparrow 1960; Dick 2001; Sekimoto et al., 2007; Beakes and Thines 2017; Buaya et al., 2019d). The present taxonomic arrangement of the oomycetes is largely based on the works of Karling (1942), Sparrow (1960) and Dick (2001), but with larger taxonomic revisions over the past 15 years (Thines and Spring 2005; Thines et al., 2015; Beakes and Thines 2017; Buaya and Thines 2019b). Peronosporomycetes is the largest oomycetes class containing three orders (Albuginales, Peronosporales, Rhipidiales) that are saprophytes (e.g. Sapromyces, Rhipidium, Salispina, Halophytophthora, Phytopythium) and parasites of various plants (e.g. Albugo, Bremia, Hyaloperonospora, Peronosclerospora, Peronospora, Phytophthora, Plasmopara, Pseudoperonospora, Pustula, Pythium), vertebrate and invertebrate animals (e.g. Lagenidium, Myzocytiopsis) (Dick 2001; Kamoun 2003; Lamour and Kamoun 2009; Thines 2014; Fawke, Doumane and Schornack
2015; Kamoun et al., 2015; Beakes and Thines 2017; Thines and Choi 2016; Derevnina et al., 2016).

The Saprolegniomycetes (Thines et al., 2015) contain two recognised orders (Saprolegniales, Leptomitales) mainly saprobes and parasites of plants/algae (e.g. Aphanomyces, Lagenisma, Ectrogella), vertebrate (e.g. Saprolegnia, Achlya) and invertebrate animals (e.g. Atkinsiella, Chlamydomyzium, Aquastella, Sommerstorffia, Leptolegnia, Blastulidium, Bolbea) (Karling 1942; Sparrow 1960; Dick 2001; Duffy et al., 2015; Buaya and Thines 2020b). The eucarpic members of the Saprolegniomycetes are mostly placed in the Saprolegniales, while the holocarpic ones are in the Leptomitales clade. The relationships in that clade are largely unclear and several holocarpic genera are assumed to belong to this group. The eucarpic members of the Saprolegniomycetes are ubiquitous and abundant in the aquatic environment (freshwater, brackish waters) and moist soil, and are important contributors to organic decomposition and nutrient recycling and can be facultative parasites (Karling 1942; Sparrow 1960; Alexopoulos, Mims and Blackwell 1996; Dick 2001; Beakes and Thines 2017). Saprolegniomycetes commonly grow an extensive network of coenocytic mycelium, and undergo both asexual and sexual reproduction (Sparrow 1960; Dick 2001). Asexual reproduction is by means of biflagellate zoospores that are dimorphic and diplanetic or polyplanetic (Sparrow 1960). Sexual reproduction is oogamous, occurring by fusion of a haploid male (antheridium) and a female (oogonium) gametangium, producing one to several diploid oospores (Dick 2001).

The early-diverging orders that branch before the main split between Peronosporomycetes and Saprolegniomycetes (Eurychasmatales, Haptoglossales, Olpidiopsidales, Diatomoph -thorales, Miraculales, Anisolpidiales, Haliphthorales) and a few unresolved families, e.g. Rozellopsidaceae, show a great diversity of lifestyles and cytological adaptations and mostly thrive in limnic and marine environments (Beakes and Sekimoto 2009; Beakes et al., 2012; Beakes and Thines 2017; Buaya et al., 2017, 2019d; Buaya and Thines, 2020a). Most species are holocarpic, and most seem to be, biotrophic parasites and either parasite of phytoplankton and algae, such as Anisolpidium, Diatomophthora, Eurychasma, Miracula, Olpidiopsis, Petersenia, Pontisma and Sirolpidium, or of invertebrate animals, such as Haptoglossa, Haliphthoros, Halioticida, Halodaphnea (Karling 1942; Sparrow 1960; Dick 2001; Hakariya et al., 2007; Sekimoto et al., 2007, 2008a, 2008b; Gachon et al., 2017; Buaya et al., 2017, 2019b, 2019d; Buaya and Thines, 2020a). While there is accumulating evidence from environmental sequences that these holocarpic pathogens are ubiquitous, especially in aquatic environments, their ecological roles are widely unknown (Strittmatter et al., 2009; Beakes and 
Sekimoto 2009; Skovgaard 2014; Scholz et al., 2015; Beakes and Thines 2017; Hassett et al., 2019). However, it is likely these holocarpic oomycetes are significant contributors to the food web stability, functioning both as prey and predator, thereby facilitating energy transfer ("oomycoloop") as well as well as triggering adaptive diversification in their habitats as observed from other biotrophic microorganisms (e.g. chytrids) (Lafferty et al., 2008; Hatcher et al., 2012; Kagami et al., 2014).

Sexual reproduction is known to occur in organisms of the early-diverging lineages (Karling 1942; Sparrow 1960; Dick 2001). But the type of oospores observed for the Peronosporomycetes and Saprolegniomycetes is an apomorphy of these groups and absent from the early-diverging lineages (Thines 2014; Beakes and Thines 2017). However, some species of Olpidiopsis (e.g. Olpidiopsis saprolegniae var. saprolegniae, Olpidiopsis achlyae, Olpidiopsis varians) produce oospore-like structures, but their formation is not well understood (Cornu 1872; Barrett 1912; Shanor 1939; McLarty 1941; Sparrow 1960; Buaya et al., 2019d). The classification of early-diverging oomycetes is mainly based on the few morphological characters available and on the development of the holocarpic thallus, zoosporangia and zoospores, as well as the mode of zoospore release and encystment (Sparrow 1960; Dick 2001; Beakes et al., 2012; Beakes and Thines 2017). As these offer only few characteristic states useful for classification, and many might have evolved multiple times, the taxonomy and phylogenetic relationships of the early-diverging oomycetes are poorly resolved as compared to the Saprolegniales and Peronosporales (Beakes and Thines 2017). Only recently, interest on the taxonomy and systematics of this group has resurged (Fletcher et al., 2015; Klochkova, Shin and Moon 2016; Buaya et al., 2017; Kwak et al., 2017; Klochkova et al., 2017; Garvetto et al., 2018; Badis et al., 2019; Garvetto et al., 2019; Buaya et al., 2019a; Buaya and Thines 2019b; Buaya et al., 2019c, 2019d; Buaya and Thines 2020a; Buaya et al., 2020c). However, investigations of early-diverging oomycetes organisms are challenging due to the obligate biotrophic nature of these parasites, and a huge effort is needed for isolating and establishing a stable dual culture in a defined chemical medium (Buaya et al., 2019c, 2020c). Without pure cultures, sequence data of these organisms are often difficult and challenging to obtain from environmental samples. However, application of advanced molecular techniques, such as single cell genomics (Garvetto et al., 2019) or plasmid cloning (Buaya et al., 2017) can be highly useful to obtain full length sequences of these organisms for taxonomic and phylogenetic investigation.

\section{General biology and characteristics of the early-diverging oomycetes}

\section{1) Morphology and Life-cycle}

As mentioned earlier in this review, early-diverging lineages of the oomycetes have rather simple morphological characters unlike the morphologically more complex species of the Saprolegniomycetes and Peronosporomycetes. All known species of the early-diverging oomycetes produce endobiotic holocarpic thalli that subsequently mature into sporangia (Karling 1942; Sparrow 1960; Dick 2001; Beakes and Thines 2017). The typical life-cycle of the early-diverging oomycetes starts as soon as an encysted zoospore attached to its host germinates. After subsequent penetration, growth and elongation, the thallus undergoes rapid differentiation. At early stages of development, the colorless plasmodial thallus is unwalled or very thin-walled, and for most basal oomycetes growth usually starts close to the host nucleus (Karling 1942; Sparrow 1960; Schnepf et al., 1978b; Dick 2001; Beakes et al., 2012; Buaya et al., 2019a), probably to enable a more efficient deployment of pathogenicity effectors. This would be analogous to the movement of the nucleus towards haustoria in obligate biotrophic pathogens (Scheler et al., 2016) where an intimate contact would likewise render host manipulation more efficient, as effectors do not have to travel a long distance to act as transcription factors. This is evident on various early-diverging species especially those that parasitize green or brown algae (e.g. Olpidiopsis schekiana, O. oedogoniarum, Eurychasma dicksonii) and diatoms (e.g. Miracula helgolandica, M. moenusica, Diatomophthora drebesii, D. gillii, D. perforans), but also the two early-diverging members of the Saprolegniomycetes parasitizing diatoms, Ectrogella bacillariacearum and Lagenisma coscinodisci (Zopf 1884; Scherffel 1925; Sparrow and Ellison 1949; Sparrow 1960; Drebes 1966; Johnson 1966; Schnepf and Drebes 1977; Raghukumar 1980; Schnepf et al., 1978a; Buaya et al., 2017; Buaya and Thines 2019b, 2020a). The majority of the earlydiverging oomycetes such as the marine parasitoids of multicellular algae (e.g. Eurychasma, Anisolpidium, Pontisma, Sirolpidium, Petersenia), diatoms (e.g. Miracula, Diatomophthora, Aphanomycopsis, Ectrogella) and aquatic oomycetes (e.g. Olpidiopsis) produces unbranched or littlebranched thalli that are either tubular or spherical (Zopf 1884; Cornu 1872; Magnus 1905; Petersen 1905; Scherffel 1925; Karling 1943; Feldmann and Feldmann 1955; Sparrow 1960; Buaya et al., 2017; Buaya and Thines 2020a). Other earlydiverging lineages produce branched thalli, such as some species that are parasites of invertebrates (e.g. Haliphthoros, Halocrusticida, Halodaphnea), but also Lagenisma, a parasite of 
centric diatoms, produces branched thalli (Vishniac 1958; Sparrow 1960; Dick 1988; Drebes 1966). The principal chemical composition of the thallus wall of early diverging oomycetes is not fully known, but it is likely to contain significant amounts of cellulose derivatives, since most species across several genera (e.g. Diatomophthora, Miracula, Olpidiopsis) exhibits positive reaction when tested with chloride -zinc and iodine solution (Friedmann 1952; Sparrow 1960; Dick 2001; Buaya et al., 2019a, 2019b).

In several species of Olpidiopsis (e.g. Olpidiopsis saprolegniae, O. achlyae, O. vexans, O. luxurians, O. varians), a number of spherical vacuoles are prominent during the midstage of sporangium development (Shanor 1939; Sparrow 1960; Barrett 1912; McLarty 1941). After subsequent differentiation, these vacuoles disappear before roundish zoospores initials and the discharge tube begin to form. The number and length of discharge tube varies and it is unclear, if this character can be used. While many species regularly form a single discharge tube per thallus or thallus segment (e.g. Diatomophthora gillii, Miracula moenusica, Olpidiopsis saprolegniae, Pontisma lagenidioides), there are several species that usually form multiple exit tubes (e.g. Ectrogella bacillariacearum, E. licmophorae, Diatomophthora perforans) (Zopf 1884; Cornu 1872; Petersen 1905; Scherffel 1925; Buaya et al., 2017, 2019a, 2019b, 2020c). Unlike other early-diverging species, several diatom-infecting oomycetes (e.g. Ectrogella bacilariacearum, Miracula helgolandica, Diatomophthora perforans subsp. pleurosigmae) show a thickening of the base of the discharge tube (Johnson 1966; Buaya et al., 2017, 2020c). It is likely that these thickenings are formed as a Spreizapparat or Spreizkörper (Scherffel 1925) for pushing apart the frustule of the diatom host during the development of the thallus into a mature sporangium (Johnson 1966). However, it is unclear and remains to be known if these "thickenings" have significant taxonomic importance (Gavetto et al., 2018). From unpublished observations (Buaya and Thines, unpublished) it seems that this character is highly variable and depends on the actual force needed during discharge tube development.

In addition to the characters mentioned above, the mode of zoospore release also differs among species in the earlydiverging lineage (Sparrow 1960). Most holocarpic species of the early diverging Saprolegniomycetes and of the species diverging before the main Peronosporomycetes/ Saprolegniomycetes split have a zoospore discharge pattern either like Olpidiopsis (e.g. Olpidiopsis saprolegniae, Pontisma lagenidioides), Saprolegnia (e.g. Ectrogella bacillariacearum, Lagenisma coscinodisci), or Achlya (e.g. Aphanomycopsis bacillariacearum, Ectrogella monostoma, E. licmophorae) (Cornu 1872; Magnus 1905; Scherffel 1925; Petersen 1905). In species with olpidiopsis-like and saprolegnia-like zoospores discharge, zoospores immediately swim away and disperse after their release (Sparrow 1960). While the olpidiopsis-like behavior is characterised by spores that swim for some time (sometimes several minutes), in species with saprolegnia-like discharge the spores quickly come to a rest (often within a minute) and form cysts from which a second generation of more vigorously-swimming zoospores emerges. Species with achlyalike discharge first release spores that are non-flagellated (aplanospores), which encyst at the orifice of the discharge tube, and undergo further development before release of zoospores from the cysts (Scherffel 1925; Canter 1949). However, it is still unclear whether those species with an achlya-like zoospores discharge pattern are bona fide members of the early-diverging oomycetes since none of them has sequence data available (Beakes and Thines 2017; Buaya et al., 2017).

All early-diverging oomycetes confirmed so far only produce pyriform to grape-seed-shaped primary zoospores that are monomorphic and might change shape, but without forming cysts. Thus, they are considered as monoplanetic or to exhibit an incomplete diplanetism (Dick 2001; Beakes and Sekimoto 2009; Beakes et al. 2012; Beakes and Thines 2017). Except for Anisolpidium, the zoospores of early-diverging oomycetes contain two anteriorly to sub-lateral inserted flagella, with a forwardly directed tinsel flagellum ornamented with mastigoneme hairs, and a whiplash flagellum trailing behind (Beakes et al., 2012; Beakes and Thines 2017). However, the mastigoneme ornamentation appears to be variable among some lineages such as Haptoglossa, which lacks mastigonemes (Beakes and Glockling 1998; Beakes et al., 2012).

Resting spores of early-diverging oomycetes are diverse and derive from various pathogen stages (Sparrow 1960; Dick 2001). In some early-diverging species zoospore cysts are converted into resting spores, e.g. in Lagenisma coscinodisci (Schnepf and Drebes 1977). The encysted zoospores can stay dormant for a longer period of time and only germinate under proper environmental conditions. However, in species of the genus Haptoglossa the encysted spores germinate into "gun cells" (Barron 1990; Barron 1987; Barron 1989; Beakes and Glockling 1998; Beakes et al., 2012). The gun cell functions like a miniature cannon containing a needle-like harpoon projectile that is capable of rupturing the cuticle of its host (usually Adineta rotifers or rhabditid nematodes), establishing a new infection site (Beakes et al., 2012). The ultrastructure and firing mechanism of gun cells has been described in detail by Beakes and Glockling $(1998,2000,2002)$ and Barron $(1980,1987)$. In Olpidiopsis, resting spores can either be formed in a manner similar to oospore formation in the crown oomycetes (see below) or from non-discharged thalli that instead of discharge 
tubes develop a thick, usually ornamented wall (Cornu 1872; Barrett 1912; Shanor 1939; Karling 1942; Sparrow 1960).

\section{2) Sexual reproduction}

Early-diverging oomycete genera do not form oospores in the manner observed in the Peronosporomycetes and Saprolegniomycetes groups as previously mentioned. The absence of canonical sexual reproduction is likely a key diagnostic feature for all early-diverging species in addition to producing monoplanetic zoospores, probably with the exception of achlyoid spore formation, either endogenous, such as in Eurychasma (Karling 1960) or exogenous (Gavetto et al., 2019). However, an obscure form of sexual reproduction is apparently occurring in several species of the genus Olpidiopsis sensu Sparrow (1960), Eurychasma dicksonii, and Anisolpidium ectocarpii (Barrett 1912; Sparrow 1960; Beakes and Thines 2017). This non-canonical reproduction has been reported many times (Cornu 1872; Barrett 1912; Coker 1923; Tokunaga 1933; Shanor 1939; McLarty 1941; Whiffen 1942; Karling 1942; Sparrow 1960), but is still not fully understood. In Olpidiopsis s.str. (Buaya and Thines 2019d), sexual reproduction is by the fusion of two thalli of unequal size, in which the smaller thallus (often referred to as companion cells or antheridium) passes its protoplasmic contents into the larger (often referred to as oogonium) (Barrett 1912; Sparrow 1960). Karyogamy is assumed to occur after the protoplasmic fusion between two different thalli (Barrett 1912; McLarty 1941). Subsequently, a thick layer of exospore material is deposited, resulting in a variety of ornamentations, which can be spiny, smooth, tuberculate, fibrillose, or irregular (Sparrow 1960). However, it remains to be demonstrated if sexual reproduction in Olpidiopsis is homologous to that of the crown groups or has evolved independently in the genus. So far sexual reproduction in early-diverging oomycetes has been reported or assumed for only few species (Barrett 1912; Coker 1923; Scherffel 1925; McLarty 1941). The most well-documented case of nonoogamous sexual reproduction among holocarpic oomycetes was documented in the diatom parasite, Lagenisma coscinodisci, which is a member of the early-diverging Saprolegniomycetes (Drebes 1966; Thines et al., 2015). In this species, encysted zoospores (zoomeiospores) conjugate forming a diploid zygote that will eventually undergo meiosis, forming several haploid spores (Schnep et al., 1978a, 1978b, 1978c). For other species, e.g. Eurychasma dicksonii, a similar mode of reproduction has been assumed, but still needs to be ascertained by detailed cytological studies (Magnus 1905; Sparrow 1934; Sparrow 1960; Sekimoto et al., 2008a).

\section{Classification and Systematics}

\section{1) Phylogenetic Relationships of the Early-diverging Oomycetes}

The early-diverging oomycetes currently comprise 8 orders and families (Dick 2001; Beakes and Thines 2017; Buaya et al., 2017, 2019d; Buaya and Thines 2020a). These includes the Miraculales, Olpidiopsidales, Eurychasmatales, Haptoglossales, Anisolpidiales, Diatomophthorales, Pontismatales, and Haliphthorales (Figure 1). The majority of these orders are monogeneric, containing only a single genus (Beakes and Thines 2017; Buaya and Thines 2020a). Miraculales probably represents the earliest-diverging lineage, and the order Haliphthorales branches just before the main Saprolegniomycetes/Peronosporomycetes split (Buaya et al., 2017; Sekimoto et al., 2007). The molecular phylogeny of the early-diverging oomycetes is mostly based on sequences of the nuclear-encoded small ribosomal subunit (18S/SSU) (Lara and Belbahri 2011; Sekimoto et al., 2007; Hakariya et al. 2007; Buaya et al., 2017, 2019d; Buaya and Thines 2020a) and mitochondrial-encoded cytochrome c-oxidase subunit II (cox2) (Hudspeth et al., 2000; Hakariya et al., 2007; Sekimoto et al., 2008a; Choi et al., 2015), as well as the cytochrome c oxidase subunit I (cox1) (Gachon et al., 2017; Garvetto et al., 2018). However, the systematics of the early-diverging lineages is still in a state of flux (Beakes and Thines 2017). This is because there are still many species and genera that are supposedly early -diverging, but for which no sequence data are available. Some have not been isolated since their original descriptions. It is also becoming apparent that the classical systematic accounts by Karling (1942), Sparrow (1960) and Dick (2001) are in many aspects not supported by molecular phylogeny and require significant revision.

\section{2) Systematic account of the early-diverging lineages, including Ectrogellaceae and Lagenismataceae (Leptomitales)}

\section{1) Miraculales: Miraculaceae (Miracula)}

Miraculales is a monogeneric order and probably represents the earliest-diverging lineage of the oomycetes (Buaya et al., 2017). The two known members of Miracula are obligate biotrophic parasites of diatoms (Hanic et al., 2009; Buaya et al., 2017; Buaya and Thines 2019b) in freshwater ( $M$. moenusica, Buaya and Thines 2019b) and marine ( $M$. helgolandica, Buaya et al., 2017) environments. The type species M. helgolandica parasitizes the diatom Pseudo-nitzschia pungens, which is known to produce the toxin domoic acid (Bates et al., 2018). The cellular ultrastructure of the parasite has revealed structures typical for early-diverging lineages 


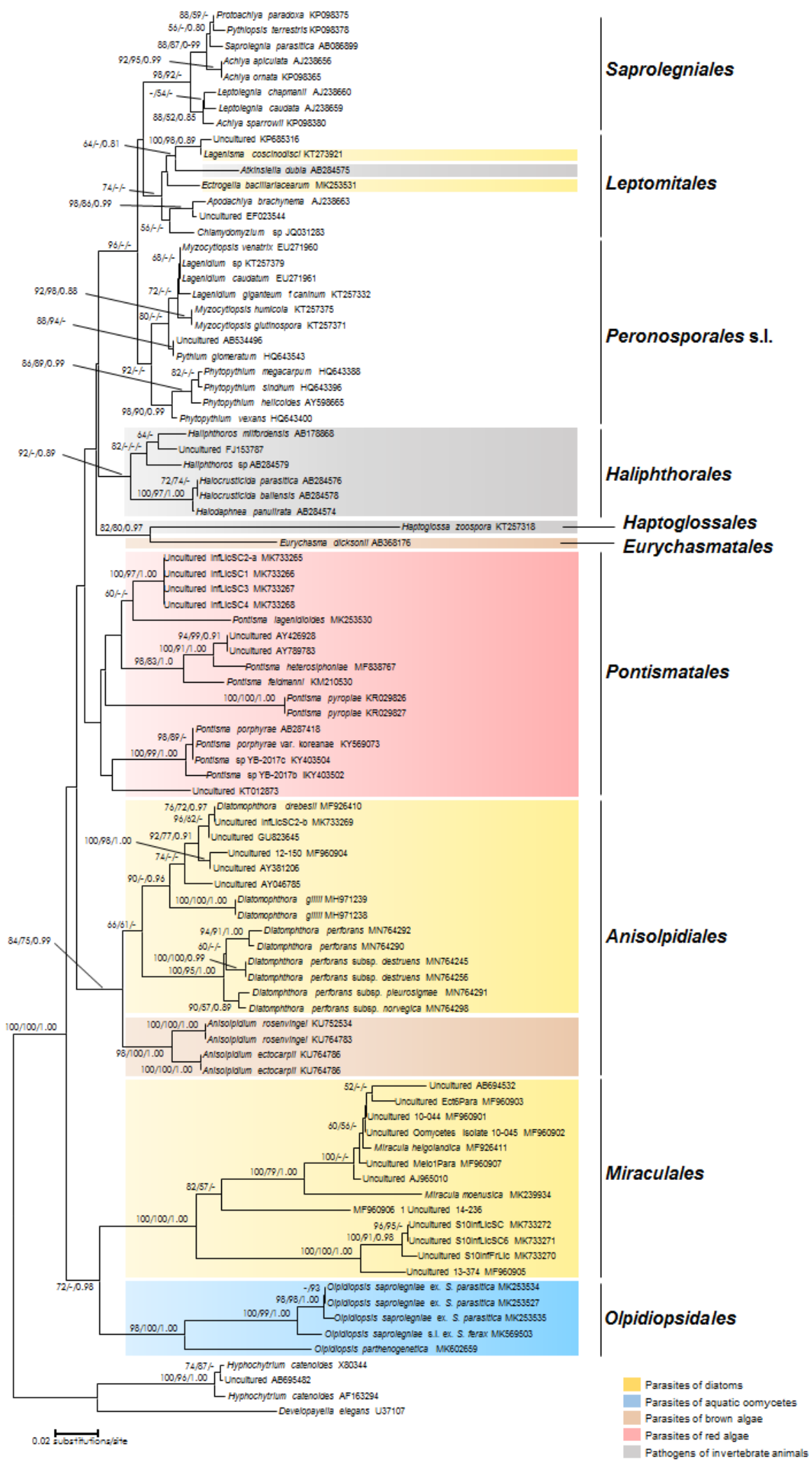

Figure 1. Minimum evolution tree based nrSSU (18S) sequences of the oomycetes. The main oomycetes orders are labelled on the right, highlighted with different colours based on their host type. Numbers on branches denote bootstrap values from minimum evolution, maximum likelihood, and Bayesian analyses, in the respective order. A dash “_" indicates less than $50 \%$ bootstrap support for the presented or a conflicting topology. Phylogenetic tree adapted from Buaya et al. (2020c). 


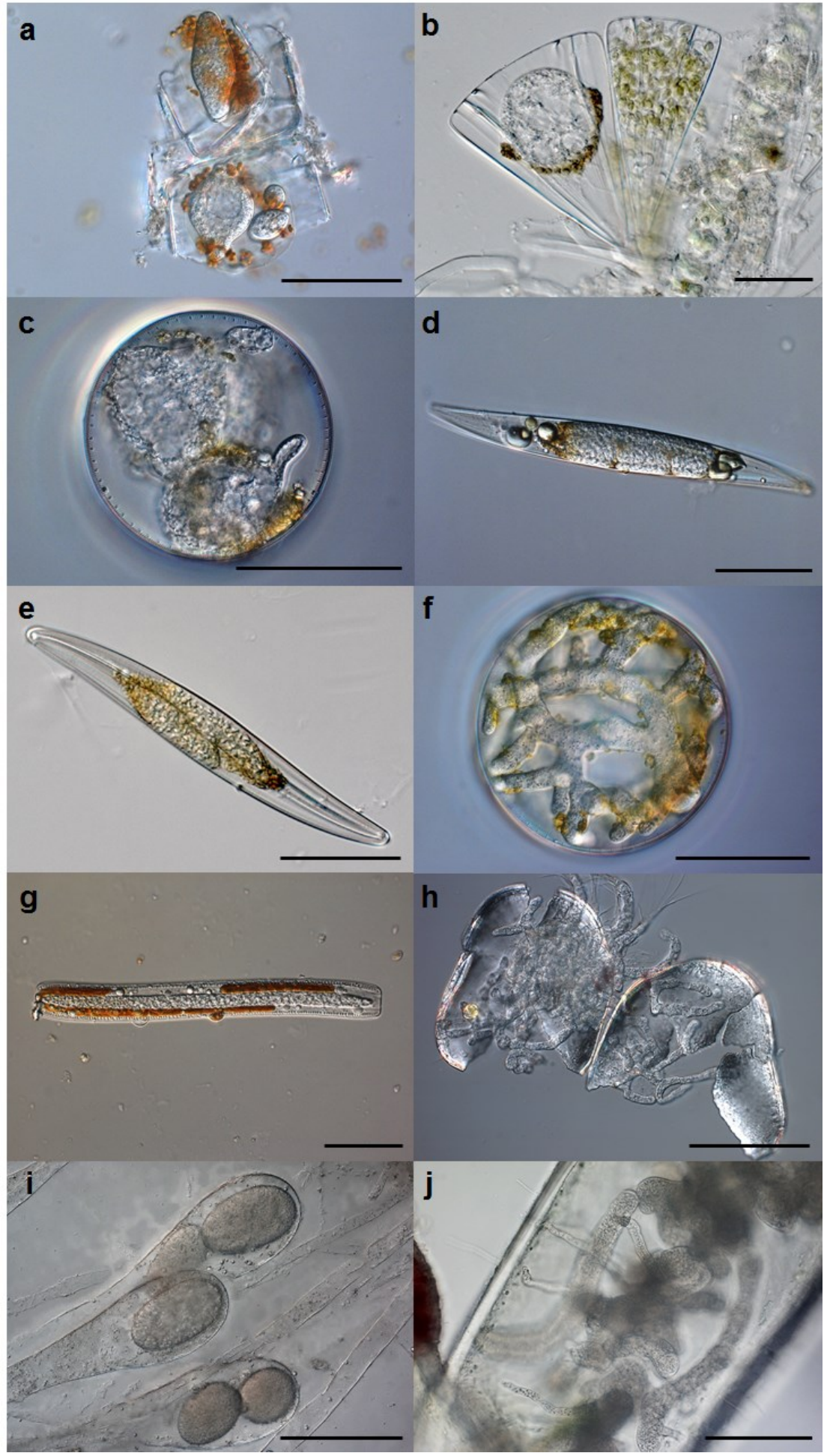

Figure 2. Light micrographs (DIC) of mature thalli of holocarpic oomycetes on various hosts. A. Miracula moenusica on the invasive diatom Pleurosira leavis; B. Diatomophthora perforans on the marine diatom Licmophora abbreviata (photo adapted from Buaya et al., 2020c); C. Diatomophthora perforans subsp. destruens on the marine diatom Coscinodiscus concinnus; D. Diatomophthora perforans subsp.pleurosigmae infecting the marine diatom Pleurosigma intermedium; E. Diatomophthora gillii infecting the freshwater diatom Gyrosigma acuminatum; F. Lagenisma coscinodisci in the marine diatom Coscinodiscus granii; G. Ectrogella bacillariacearum in the freshwater diatom Nitzschia sigmoidea (photo adapted from Buaya and Thines 2020a); H. Bolbea parasitica parasitising a freshwater ostracod (photo adapted from Buaya and Thines 2020b); I. Olpidiopsis saprolegniae var. saprolegniae parasitising in Saprolegnia parasitica; J. Pontisma lagenidioides in the marine red alga Ceramium rubrum (photo adapted from Buaya et al., 2019d). Scale bars: A, B, D, E, G $=50 \mu$ m; C, F, H, $\mathrm{I}, \mathrm{J}=100 \mu \mathrm{m}$. 
(Hanic et al., 2009). The second species, M. moenusica (Figure 2A) has been studied less, but it is noteworthy that its host diatom, Pleurosira laevis is an invasive species in freshwater aquatic environments (Gherardi 2007; Buaya and Thines 2019b). If M. moenusica has been introduced together with its host or the parasitoid has jumped hosts to the alien species, a pattern frequently found in obligate parasites (Thines 2019), needs to be revealed by future studies.

\section{2) Olpidiopsidales: Olpidiopsidaceae (Olpidiopsis)}

Olpidiopsidales (Dick 2001; Buaya et al., 2019d) is also a monogeneric order, and one of the earliest-diverging lineages of the oomycetes. The order has been previously been used as a catch-all for simple holocarpic oomycetes, but has been shown to be largely polyphyletic, leading to substantial revision (Dick 2001; Beakes and Thines 2017; Buaya et al. 2019d). The phylogenetic placement of the type species, $O$. saprolegniae from Saprolegnia parasitica (Figure 2I), had revealed that Olpidiopsidales are largely unrelated to the holocarpic parasites of marine red algae (Buaya et al., 2019d). This led to a resurrection of Pontismatales and a transfer of all holocarpic parasites of red algae to the genus Pontisma (Buaya et al., 2019d), as previously suggested by Dick (2001). So far, only two species of Olpisiopsidales s.str. have been sequenced, the type species and a newly described species, $O$. parthenogenetica. The type species and other Olpidiopsis parasites of aquatic oomycetes are known to be widely occurring in freshwater habitats and moist soil (Karling 1942; Sparrow 1960). The remaining unsequenced Olpidiopsis that are obligate endobiotic parasite of aquatic oomycetes and fungi include, $O$. saprolegniae var. levis, $O$. achlyae, $O$. fusiformis, $O$. braziliensis, $O$. index, $O$. varians, $O$. spinosa, $O$. incrassata, $O$. major, $O$. vexans, $O$. luxurians, $O$. aphanomycis, $O$. gracile, $O$. pythii, O. curvispinosa, O. brevispinosa, O. verrucosa, $O$. myzocytia, and $O$. karlingiae. For some of these species placements in other genera have been suggested, but without molecular phylogenetic investigations that might help to pinpoint synapomorphies, no decision can be made on this. The taxonomic placement of several Olpidiopsis species parasitising marine and freshwater algae (O. schenkiana, O. oedogoniarum, $O$. fibrillosa, O. appendiculata, O. zopfii, O. andreei, $O$. magnusii) remains uncertain, because none were studied for their molecular phylogeny.

\section{3) Eurychasmatales: Eurychasmataceae (Eurychasma)}

The genus Eurychasma has often been placed in the Saprolegniales, but phylogenetic investigations have shown that it forms a very early diverging lineage of the oomycetes (Sekimoto et al., 2008a; Beakes and Thines 2017), and often groups with moderate support with the genus Haptoglossa (Sekimoto et al., 2008a; Beakes and Sekimoto 2009; Strittmatter et al., 2013; Buaya and Thines 2020a). The type species Eurychasma dicksonii is the only confirmed member of the genus and is a biotrophic parasite of various brown algae (Magnus 1905; Sparrow 1960, Küpper et al., 2006; Gachon et al., 2009). This parasite is known to be widely distributed in the temperate regions and has been extensively studied with respect to its physiology and cellular ultrastructure (Müller et al., 1999; Gachon et al., 2009; Tsirigoti et al., 2013; Grenville-Briggs et al., 2011; Tsirigoti et al., 2015; Strittmatter et al., 2016). Aside from $E$. dicksonii, E. succulus has been described, which is parasitic to the rhodophyte algae Halosaccion ramentaceum and Rhodymenia palmata (Petersen 1905). However, the taxonomic status of this species is difficult to assess. Petersen, who described the species, later did not consider it as different from E. dicksonii (conversation cited in Sparrow 1960), but as the host is unrelated to the host of E. dicksonii (red algae vs. brown algae), it would be expected that the species are distinct. However, sequence data for E. succulus are needed to clarify this situation.

As the Eurychasmatales have not been formally named, as the name "Eurychasmales" by Sparrow (1976) lacked a description, this is done here.

Eurychasmatales A. Buaya et Thines ord. nov. Mycobank MB 835589

Type: Eurychasma Magnus, Hedwigia 44: 348 (1905).

Description: Thallus holocarpic, usually leading to an enlargement of the host cell, zoospore cleavage from a large central vacuole, encysting within the thallus as part of their maturation, zoospores hatching from the cysts escape through one to several exit tubes formed during the maturation of zoospores.

\section{4) Haptoglossales: Haptoglossaceae (Haptoglossa)}

Haptoglossales (Dick 2001; Beakes and Thines 2017) is a monogeneric order often grouping with Eurychasmatales (Hakariya et al., 2007; Sekimoto et al., 2008a; Buaya et al., 2019d). The genus Haptoglossa contains 12 species ( $H$. beakesii, $H$. dickii, $H$. elegans, $H$. erumpens, $H$. heteromorpha, $H$. heterospora, H. humicola, H. intermedia, H. mirabilis, $H$. northumbrica, $H$. polymorpha, and $H$. zoospora), all obligate endobiotic parasites of various rotifers and nematodes (Barron 1990; Glockling and Beakes 2000b, 2001; Glockling and Serpell 2010). All species but H. heterospora (Drechsler 1940) are terrestrial (Beakes and Thines 2017). As an apomorphy, Haptoglossa species produce "gun cells", which is a specialised infection structure that enables the parasite to penetrate its host 
animal (Beakes et al., 2012). Several species in the genus Haptoglossa have been studied using electron microscopy, especially with respect to "gun cell" ultrastructure and mechanistic function (Barron 1987; Lee et al., 1992; Glockling and Beakes 2000b, 2002; Beakes et al., 2012). However, there are so far no clear-cut synapomorphies that could be used to differentiate subgroups in the genus.

\section{5) Anisolpidiales}

\subsection{1) Anisolpidiaceae (Anisolpidium)}

Anisolpidiaceae is a monogeneric family, and frequently groups with the allied genus, Diatomophthora (Gachon et al., 2017; Buaya et al., 2019d, 2020c). If the grouping reflects a host-jump of a common ancestor to members of the Straminipila or is coincidental because of the limited knowledge on holocarpic oomycetes needs to be clarified by future studies. So far, only two species of this family have been included in molecular phylogenetic investigations, A. ectocarpii and $A$. rosenvingei. The phylogenetic placement of the type species (A. sphacellarum) remains unknown (Gachon et al., 2017). The genus contains the species, A. sphacellarum, $A$. ectocarpii, A. rosenvingei, A. elongatum, A. saprobium, $A$. joklianum, A. minutum, and A. olpidium, A. stigeoclonii), which are all parasites of marine brown algae (e.g. Sphacelaria, Ectocarpus, Pylaiella) (Karling 1943; Canter 1950; Karling 1968, 1977; Dick 2001).

\subsection{2) Diatomophthoraceae (Diatomophthora)}

Diatomophthoraceae is a monogeneric family (Buaya and Thines 2020a). The genus Diatomophthora often forms a monophyletic group with Anisolpidium, and contains a variety of relatively little-studied parasitoids of diatoms (Buaya and Thines 2020a; Buaya et al., 2020c). Diatomophthora has been previously assigned to Olpidiopsis together with several species of marine red-algae parasites, an assemblage which was long thought to be polyphyletic or paraphyletic (Beakes and Thines 2017; Buaya et al., 2019d; Buaya and Thines, 2020a). The recent phylogenetic placement of the type species of Olpidiopsis (O. saprolegniae) shows that the olpidiopsis-like diatom parasitoids are unrelated to Olpidiopsis (Buaya and Thines 2020a). It was speculated that the lineage would be related to Ectrogella due to host-range similarities and thallus morphology (Garvetto et al., 2018, 2019). However, recent phylogenetic investigations of the type species of Ectrogella, Ectrogella bacillariacearum, revealed that the genus actually belongs to the early diverging Saprolegniomycetes and does not diverge earlier (Buaya and Thines 2020a). Thus, the genus Diatomophthora was introduced to accommodate the monophyletic clade containing olpidiopsis-like diatom parasites
(Buaya and Thines 2020a). So far, only six species of this genus have been sequenced, the type species $D$. drebesii, D. gillii (Figure 2E) and the recently introduced three subspecies of $D$. perforans (Figure 2B) (D. perforans subsp. norvegica, $D$. perforans subsp. destruens (Figure 2C), D. perforans subsp. pleurosigmae (Figure 2D)) (Buaya et al., 2017, 2019a, 2020c). There are still several diatom-infecting oomycetes that do not have sequence data for them available, yet, and it is possible that some of these belong to this genus, Lagenidium, Ectrogella, or Miracula. These include several species from the genera Ectrogella (E. monostoma, E. gomphonematis, E. licmophorae, E. eunotiae), Aphanomycopsis (A. bacillariacearum) and Lagenidium (L. enecans, L. brachystomum, L. cyclotellae) (Zopf 1884; Petersen 1905; Scherffel 1925; Friedmann 1952).

\section{6) Pontismatales: Pontismataceae (Pontisma)}

The monogeneric order Pontismatales (Buaya et al., 2019d) has only been recently introduced. Because of its hostrange and "olpidiopsis-like" thallus, many parasites of red algae have been assigned to the Olpidiopsidales together with the genera Olpidiopsis, Pontisma, Sirolpidium and Petersenia (Petersen 1905; Karling 1942; Sparrow 1960). However, recent phylogenetic investigation of the type species of Pontisma, $P$. lagenidioides (Figure 2J), shows that this genus is unrelated to Olpidiopsidales, which are probably restricted to oomycete hosts and forms a monophyletic grouping together with other parasites of marine red algae ( $P$. heterosiphoniae, $P$. feldmanii, $P$. pyropiae, $P$. porphyrae, $P$. porphyrae var. koreanae, $P$. bostrychiae, $P$. muelleri, $P$. palmariae), previously assigned to the genus Olpidiopsis (Aleem 1952; Sekimoto et al., 2008b, 2009; Fletcher et al., 2015; Klochkova et al., 2016, 2017; Badis et al., 2019; Buaya et al., 2019d). Thus, all holocarpic oomycete parasites of red algae were transferred to the genus Pontisma (Buaya et al., 2019d). Two enigmatic parasites of marine algae remain unsequenced - Sirolpium and Petersenia. It is likely that Petersenia is closely related to Pontisma because of its lifecycle and morphological similarities, and the marine green algae parasite Sirolpidium might, for the same reason probably be also closely related to Pontisma.

\section{7) Haliphthorales: Haliphthoraceae (Haliphthoros)}

The order Haliphthorales is probably monophyletic and might represent the sister group of the Saprolegniomycetes and Peronosporomycetes oomycetes (Sekimoto et al., 2007; Beakes and Sekimoto 2009; Buaya and Thines 2020a). The type genus of the order is, Haliphthoros (H. milfordensis, H. philippinensis, $H$. zoophthorum, $H$. sabahensis) and contains various crustaceans parasites (Vishniac 1958; Hatai et al., 1980; Dick 2001; Beakes and Thines 2017). The genera Halioticida ( $H$. 
noduliformans), Halocrusticida ( $H$. awabi, $H$. baliensis, $H$. entomophaga, $H$. hamanaensis, $H$. okinawaensis, $H$. parasitica) and Halodaphnea (H. pinulirata) are additional members of this group (Kitancharoen and Hatai 1995; Nakamura and Hatai 1995; Hatai et al., 2000; Muroasa et al., 2009). However, as there are little to no clear-cut morphological differences between the groups and all have a similar lifestyle, they are probably better considered to be synonymous with Haliphthoros. Several species in the genus are likely synonymous, as well (Beakes and Thines 2017). The species belonging to Haliphthoros s.l. form irregularly segmented, branched thalli and are the only known members of the earlydiverging oomycetes that can be cultured apart from their host (Vishniac 1958; Sekimoto et al., 2007; Hatai 2012).

\section{8) Leptomitales}

Even though the Leptomitales are not belonging to the early-diverging oomycetes, but are forming the earliestdiverging lineage of the Saprolegniomycetes (Buaya \& Thines 2020b), the two families Ectrogellaceae and Lagenismatatceae are discussed here, as they were previously speculated to belong to diverge before the split of the Peronosporomycetes and Saprolegniomycetes. Because of the currently unclear phylogenetic relationships within the Leptomitales other genera, such as Blastulidium and Clamydomyzium are not discussed here. For some additional comments on the Leptomitales, the reader is referred to Buaya and Thines (2020b). Also the placement in the two separate families needs to be viewed as provisional, as the nomenclature of the Leptomitales requires substantial revision after phylogenies with higher resolution and covering more taxa become available.

\subsection{1) Ectrogellaceae (Ectrogella)}

Ectrogellaceae is a monogeneric family initially speculated to be a member of the early-diverging oomycetes (Garvetto et al., 2018, 2019). However, recent phylogenetic investigations of the type species E. bacillariacearum (Figure $2 \mathrm{G})$ shows that this genus belongs to the early-diverging lineages of the Saprolegniomycetes (Buaya and Thines 2020a), in line with earlier taxonomic accounts of Karling (1942), Sparrow (1960) and Dick (2001). It remains to be investigated if other diatom-infecting species (E. monostoma, $E$. gomphonematis, E. eunotiae, E. brachystoma, E. cyclotellae, E. licmophorae, E. eurychasmoides) and algal parasites (E. marina, E. lauderia, E. dicksonii, E. besseyi) that are traditionally associated to this group are bona fide members of this genus, since sequence data are not yet available for these (Petersen 1905; Scherffel 1925; Sparrow and Ellison 1949; Friedmann 1952; Feldmann and Feldmann 1955; Sparrow 1960;
Dick 2001). However, the fact that some of the species, e.g. $E$. monostoma do not exhibit a clear-cut diplanetism casts doubts on their relatedness to the type species, E. bacilliacearum.

\subsection{2) Lagenismataceae (Lagenisma)}

The family Lagenismataceae (Dick 2001) is monotypic, containing a single genus and species, which is an obligate parasite of large marine centric diatoms (Drebes 1966; Thines et al., 2015; Beakes and Thines 2017). The parasite is known to occur in both temperate and tropical climates, especially during blooms of its diatom hosts in the genera Coscinodiscus $(C$. granii, C. concinnus, $C$. wailesii, $C$. radiatus) and Palmeria ( $P$. hardmaniana) (Parson 1962; Johnson 1966; Gotelli 1971; Grahame 1976; Wetsteyn and Peperzak 1991; Thines et al., 2015; Buaya et al., 2019c). Lagenisma (Figure 2F) was initially speculated to belong to the early-diverging oomycetes because it produces a holocarpic thallus and because of its sexual reproduction by zoomeiospores. However, Thines et al., (2015) have shown that it is embedded within the early-diverging lineage of the Saprolegniomycetes, close to Atkinsiella and Bolbea (Figure 2H) (Thines et al., 2015; Buaya and Thines 2020b). Later, Buaya and Thines (2020a) have shown that Ectrogella belongs to the same group. The parasite produces diplanetic zoospores, which are distinctive characters for species belonging to the Saprolegniomycetes (Schnepf and Drebes 1977; Schnepf et al., 1978a, 1978b, 1978c; Schnepf and Heinzmann 1980). Some other unsequenced holocarpic species (e.g. Ectrogella licmophorae, Pythiella vernalis) are also known to produce diplanetic zoospores (Scherffel 1925; Couch 1935; Sparrow 1960). It seems plausible that these species are also members of the Saprolegniomycetes, though this needs to be further investigated in future studies.

\section{9) Genera incertae sedis}

There are various genera that so far have not been included in phylogenetic investigations and which morphology does not allow for an unambiguous assignment to one of the groups mentioned above. While the ultrastructure of the pollen parasite Ducellieria chodatii supports the view that the species is belonging to the oomycetes and might be diverging after the Peronosporomycetes/Saprolegniomycetes split (Hesse et al., 1989), the situation is even less clear for other genera. It is even unclear, if several of these genera, such as Pseudosphaerita and Rozellopsis are belonging to the oomycetes or are probably better placed in other taxonomic groups. As we feel that speculating regarding this is associated with a high degree of uncertainty, we refrain from doing so. 


\section{Ecology and host-range of the early-diverging oomycetes}

\section{1) Occurrence and host-range}

The early-diverging oomycetes are ubiquitous and widely distributed, especially in the aquatic environment (Karling 1942; Sparrow 1960; Dick 2001; Beakes and Thines 2017). In marine environments, they are known to infect diatoms (Buaya et al., 2017; Garvetto et al., 2018; Buaya et al., 2020c), multicellular algae (rhodophytes, phaeophytes, chlorophytes) (Sekimoto et al., 2008a; Klochkova et al. 2016, 2017; Badis et al., 2019; Buaya et al., 2019d) and invertebrate animals (Hatai et al., 2000; Leaño 2002; Sekimoto et al., 2007). Likewise, these parasites are also widely occurring in freshwater, parasitizing diatoms (Zopf 1884; Gill 1893; Scherffel 1925; Friedmann 1952; Buaya et al., 2019a, 2019b), filamentous green algae (de Wildeman 1895, 1896; Canter 1949), and invertebrate animals (Barron 1990; Glockling and Beakes 2000a, 2000b, 2001; Glockling and Serpell 2010). However, despite their widespread occurrence, little is known regarding the ecology of these organisms, especially, on how they interact with other organisms, their occurrence and roles in nature (Skovgaard 2014; Scholz et al., 2015). To date, almost all of the known early-diverging oomycetes were recorded from temperate regions, and knowledge about the existence of this group in the tropics is scarce (Grahame 1976; Hatai et al., 1980; Raghukumar 1987; Leaño 2002; Chukanhom et al., 2003; Strittmatter et al., 2009; Raghukumar 2009). In terms of hostrange, knowledge is fairly limited as well, and for the past decades there were only a few studies conducted on this aspect (Drebes 1966; Müller et al., 1999; Strittmatter et al., 2009; Gachon et al., 2009). Perhaps the last extensive host-range study was conducted almost eighty years ago on the aquatic, oomycete-parasitic genus Olpidiopsis (Shanor 1940). At present, there were only a few host-range studies conducted on two pathogens of marine algae, Eurychasma dicksonii, and diatoms, Lagenisma coscinodisci (Drebes 1966; Müller et al., 1999; Gachon et al., 2009; Strittmatter et al., 2009; Buaya et al., 2019c). However, it is becoming clearer that a remarkable diversity in terms of host ranges exists. While Eurychasma dicksonii seems to have a rather broad host range, at least under laboratory conditions, species of Olpidiopsis seem to be more specialised, often even below the genus level (Shanor 1940).

Application of molecular techniques in ecological studies of oomycetes has recently expanded the present understanding on the diversity and distribution of these seemingly intractable organisms (Beakes and Sekimoto 2009). A few community sequencing studies have been conducted on marine oomycetes and revealed environmental sequences that are thought to correspond to some known and many unknown species and higher-level clades of the early diverging lineages, suggesting that these organisms are indeed widespread, with many species still awaiting discovery (Moon-van der Staay et al., 2001; Massana et al., 2004, 2006; Garvetto et al., 2018; Hassett et al., 2019)

\section{1) Parasites of Algae}

Several early-diverging oomycetes species are known to be obligate biotrophic parasites of marine and freshwater algae (Karling 1942; Sparrow 1960; Dick 2001). In marine environments, the majority of these are infecting red-algae (Pontisma, Petersenia) and a smaller number is parasitic in brown (Anisolpidium, Eurychasma) or green algae (Sirolpidium) (Petersen 1905; Magnus 1905; Karling 1942, 1943; Buaya et al., 2019d). In freshwater environments, early-diverging oomycetes were only reported from a small number of species of filamentous green algae, usually as Olpidiopsis species (Zopf 1884; de Wildeman 1896; Scherffel 1925). The host-range of most algae-infecting parasites is still not well established, except for E. dicksonii (Müller et al., 1999; Gachon et al., 2009). However, based on morphological identifications, several algal parasites seem to have rather broad host-ranges (e.g. E. dicksonii, $P$. lagenidioides), while some are assumed to have rather narrow host-ranges (e.g. $P$. bostrychiae, $P$. porphyrae) (Sekimoto et al., 2008b; Strittmatter et al., 2009; Sekimoto et al., 2009). The genus Pontisma is widespread, which is also reflected by the fact that it has the highest number of species recorded (Petersen 1905; Sekimoto et al., 2008b, 2009; Klochkova et al., 2016, 2017; Badis et al., 2019). It is noteworthy that the type species, $P$. lagenidioides (Figure 2a) infects often only old and moribund tissues, which suggests that it has little effect on its host populations. The other species have rarely been reported to cause massive losses in natural ecosystems as well (Petersen 1905; Magnus 1905; Sparrow 1936; Gachon et al., 2009; Tsirigoti et al., 2013; Gachon et al., 2017; Badis et al., 2019), indicating a well-balanced host pathogen relationship. If Petersenia (P. lobata, P. palmariae, $P$. pollagaster) is distinct from Pontisma remains to be demonstrated. It is conceivable that its lobed thallus represents a beginning compartmentalisation, which is absent in most species of Pontisma, but pronounced in P. lagenidioides, to which, in term of infection strategy, Petersenia is closely connected. Also, Sirolpdium (S. bryopsidis) seems to favour old thallus parts and has probably only a limited detrimental effect on its host populations. Anisolpidium (A. sphacellarum, A. ectocarpii, A. rosenvingii) and Eurychasma (E. dicksonii) have rarely been recorded (Magnus 1905; Sparrow 1934; Karling 1942, 1943; Sparrow 1943; Pueschel and van der Meer 1985; Dick 2001). The scarcity of the records does not necessarily mean that the 
species are indeed rare, it could also be that they are rather attenuated pathogens, so symptoms are not conspicuous, as, e.g. it is possible to co-culture Eurychasma and some of its host under optimal growth conditions for several months (Ploch and Thines, unpublished experiments).

\section{2) Parasites of Diatoms}

Diatom-infecting early-diverging oomycetes are widely occurring, containing more than a dozen species in various genera (Karling 1942; Sparrow 1960; Dick 2001). Most of these parasites were recorded from marine environments and almost all were isolated from temperate regions (Sparrow 1960). The ecological role and occurrence of these parasitoids remains largely speculative (Scholz et al., 2015). In both freshwater and marine habitats, the occurrence of these parasites often seems to coincide with the bloom of their respective host, and most species seem to favour cooler temperatures, occurring in high abundance during spring or autumn (Sparrow 1936, 1960; Hanic et al., 2009; Beakes and Thines 2017; Buaya et al., 2017, 2019a, 2019b). However, this remains to be proven systematically, since reports of diatom parasitoids are rather rare. The bulk of the known species has been assigned to the genus Ectrogella (Zopf 1884). However, the phylogenetic affinity of most of these remains unresolved since many have not yet been investigated for their molecular phylogeny. The host-range of these parasitoids remains also largely unknown, even though it has been speculated that there is some degree of host specificity (Sparrow 1936; Drebes 1966; Gotelli 1971; Wetsteyn and Peperzak, 1991; Garvetto et al., 2018), and to date, only three species ( $L$. coscinodisci, $D$. perforans subsp. destruens, $D$. perforans subsp. pleurosigmae) has been successfully cultivated together with its host diatom (Schnepf and Drebes 1977; Buaya et al., 2019d, 2020c) over longer periods of time.

\section{3) Parasites of Aquatic Oomycetes}

Early-diverging oomycetes that are obligate parasites of aquatic oomycetes (Saprolegniales, Pythiales) are widely distributed in various freshwater environments (Karling 1942; Sparrow 1960; Dick 2001). The majority of these parasitoids are members of the genus Olpidiopsis, but also Lagenidium destruens, Petersenia irregulare, Pythiella besseyi, P. vernalis, and Pythium utriculoba have been reported as parasites of aquatic oomycetes (Cornu 1872; Maurizio 1895; Barrett 1912; Coker 1923; Tokunaga 1933; Shanor 1939; McLarty 1941; Karling 1942; Whiffen 1942; Sparrow 1960; Miller 1962). The ecological role of these organisms with respect to regulating the pathogen pressure on e.g. invertebrates remains largely unknown. In a cross-infection study conducted with five parasite species (O. saprolegniae, O. varians, $O$. fusiformis, $O$. incrassata, O. luxurians, $O$. aphanomycis), results have shown that a few are able to affect a broader host range, while others apparently infect only single host species (Shanor 1940). The genus Rozellopsis, is another interesting group of aquatic oomycetes parasites, that is likely to be a member of the earlydiverging lineages (Karling 1942). This genus contains four species that are biotrophic parasites of Saprolegniaceae $(R$. septigena, $R$. simulans), and Pythiaceae ( $R$. inflata, $R$. waterhouseii) (Fischer, 1882; Butler, 1907; Karling, 1942). However, taxonomic placement of the genus still remains unresolved, since none of the species has been included in molecular phylogenies to date, and it can even not be excluded that the genus does not belong to the oomycetes.

\section{4) Parasites of Invertebrate Animals}

Early-diverging oomycetes that parasitize invertebrate animals are also ubiquitous and widely occurring in aquatic and terrestrial environments (Sparrow 1960; Beakes and Sekimoto 2009; Beakes and Thines 2017). Among the hosts of marine species of the genus Haliphthoros s.l. are several crustaceans (e.g. Homarus americanus, Penaeus monodon, Haliotis sieboldii) cultivated in aquaculture or with economic importance in fishing (Fisher et al., 1975; Kitancharoen and Hatai 1995; Chukanhom et al., 2003). The genus Haptoglossa is a widespread, mostly terrestrial obligate endobiotic parasite of invertebrate animals (Beakes et al., 2012). Most of the species of Haptoglossa parasitize nematodes (e.g. H. beakesii, $H$. erumpens), and a few others are parasitic to rotifers $(H$. mirabilis, H. elegans) (Beakes and Sekimoto 2009). Their regulating effects on their often abundant host populations are poorly understood, but the widespread nature, species-richness of the genus, and the deep divergence of the lineages within suggests that there is a longstanding evolutionary equilibrium between the parasitoids and their respective hosts.

\section{2) Methods of Study and Cultivation}

Most of the early-diverging oomycetes are widely distributed and can be readily isolated from their natural environments after a thorough screening process. Methods for the collection, isolation and culturing these parasites can be found in Karling (1942), Sparrow (1960) and Dick (2001). Fresh aquatic samples (e.g. water, mud, filamentous algae, floating organic debris, insect carcasses) can be directly collected from the field. Field collection of basal oomycetes infecting phytoplankton are usually done using a plankton net, preferably with mesh size of $20 \mu m$ (Hanic et al., 2009; Thines et al., 2015; Buaya et al., 2017). Screening for parasites and isolation is probably most efficient using an inverted light microscope 
(Buaya et al., 2017, 2019c, 2019d; Buaya and Thines 2020a). Early-diverging oomycetes that are parasites of diatoms (e.g. Miracula helgolandica, Diatomophthora gillii, Ectrogella bacillariacearum, Diatomophthora perforans) and algae (e.g. Pontisma lagenidioides, Eurychasma dicksonii) can be directly isolated using pipettes and scalpels, respectively (Müller et al., 2008; Buaya et al., 2017, 2019a, 2019d; Buaya and Thines 2020a; Buaya et al., 2020c). Others require some additional techniques for isolation such as baiting (Karling 1942; Sparrow 1960; Karling 1981). Baiting is especially useful for isolating Olpidiopsis (e.g. O. saprolegniae, O. achlyae) species (Barrett 1912; Coker 1923; Shanor 1939; McLarty 1941; Buaya et al., 2019d). Samples (e.g. water, mud, soil sediments, organic substance) are diluted with autoclaved pond water, baited with various seeds (e.g. sesame, hemp) and then incubated for several days (Sparrow 1960; Karling 1981; Beakes and Thines 2017). Baiting is also useful for the isolation of invertebrate animal parasites such as Haptoglossa (Beakes and Thines 2017). Removal of the bacterial or fungal contaminants can be achieved by the addition of antibiotics to the medium or through stepwise rinsing using sterile water (Sparrow 1960). After isolation, specimens can be processed for morphological characterisation and also for molecular investigations. So far, only a handful of the early-diverging holocarpic oomycetes can be cultivated in agar medium. These include species that are marine parasites of various crustaceans from the genus Haliphthoros s.l. (H. milfordensis, H. philippinensis), which can be cultivated using PYG medium (peptone, yeast extract and glucose agar) or synthetic sea-water medium containing glucose and sodium aspartate dissolved in sterile sea water (Vishniac 1958; Hatai et al., 1980; Chukanhom et al., 2003). A few earlydiverging oomycetes species were also cultivated together with their host, such as Olpidiopsis spp., Eurychasma dicksonii, and the diatom-infecting oomycetes Lagenisma coscinodisci (Shanor 1940; Müller et al., 2008; Buaya et al., 2019c) and Diatomophthora (Buaya et al., 2020c). If (temporal) cultures are aimed for, it is important to first isolate some healthy hosts and to establish their culture, before dividing it in half and inoculating half of the culture for each asexual cycle of the parasites.

\section{Practical and economic importance}

Only a few early-diverging oomycetes are known to infect various economically important marine algae and crustaceans (Strittmatter et al., 2009; Beakes and Thines 2017). In marine algae, the widely cultivated red-algae Porphyra spp. is periodically parasitised by two Pontisma species ( $P$. porphyrae, $P$. bostrychiae) causing a disease known as "chytrid blight" (Sekimoto et al., 2008b, 2009; Li et al., 2010; Klochkova et al., 2012). Porphyra spp. are widely cultivated in East Asia (Japan, Korea, China), where they are used for nori production (Pereira and Yarish 2008; Baweja et al., 2016). Pontisma spp. cause spots, holes and discolorations, affecting the quality and yield of the diseased crop (Ding and Ma 2005; Sekimoto et al., 2008b, 2009; Strittmatter et al., 2009).

The eucarpic oomycete Pythium porphyrae is also known to infect Porphyra, occurring simultaneously with the Ponstima porphyrae and $P$. bostrychiae causing a "red-rot" disease (Kawamura et al., 2005; Park et al., 2006; Park and Hwang 2015). Aside from marine algae, as mentioned before, a few species of the genus Haliphthoros s.l. ( $H$. milfordensis, $H$. philippinensis, H. sabahensis, H. okinawaensis) are also known to have economic impact on marketed marine crustaceans (shrimp, lobster, mud crab) (Vishniac 1958; Hatai et al., 1980; Nakamura and Hatai 1995; Strittmatter et al., 2009; Lee et al., 2017). These parasites usually attack the larvae of crustaceans causing mycotic infections subsequently killing the larvae (Fisher et al., 1975; Tharp and Bland 1977; Leaño 2002). Apart from these negative impacts, it can be assumed that some holocarpic oomycetes affecting toxic diatoms have a positive economic impact by controlling harmful algal blooms (Hanic et al., 2009; Lelong et al., 2012; Trainer et al., 2012; Buaya et al., 2017; Garvetto et al., 2018; Bates et al., 2018)

\section{Acknowledgements}

ATB is grateful to Katholischer Akademischer Ausländer Dienst (KAAD) for the doctoral fellowship, Stiftung zur Förderung der internationalen Beziehungen der GoetheUniversität Frankfurt am Main, and Senckenberg Biodiversity and Climate Research Center (SBiK-F) for the add-on scholarships; We are also grateful to Sebastian Ploch for laboratory support. MT is supported by LOEWE in the framework of the LOEWE Centre for Translational Biodiversity Genomics (TBG), funded by the Ministry of Science of the Government of Hesse.

\section{Literature Cited}

Alabi, R.O., 1972. Natural occurrence of Aqualinderella fermentans in Nigeria. Transactions of the British Mycological Society, 59: 103-105.

Aleem, A.A., 1952. Olpidiopsis feldmanii sp. nov., Champignon marin parasite d'Algues de la famille des Bonnemaisoniacees. C.R. Acad. Sci. Paris, 234:2648-2650

Alexopoulos, C.J., C.W. Mims \& M.A. Blackwell, 1996. Introductory Mycology, Wiley, New York. 880 pp. 
Badis Y., T.A. Klochkova, M. Strittmatter, A. Garvetto, P. Murua, J.C. Sanderson, G.H. Kim \& M.M. Gachon, 2019. Novel species of the oomycete Olpidiopsis potentially threaten European red algal cultivation. Journal of Applied Phycology, 31: 1239-1250.

Baldauf S.L., A.J. Roger, I. Wenk-Siefert \& W.F. Doolittle, 2000. A kingdom-level phylogeny of eukaryotes based on combined protein data. Science, 290: 972-977.

Barrett J.T., 1912. Development and sexuality of some species of Olpidiopsis (Cornu) Fischer. Annals of Botany London, 26: 209-238.

Barron, G.L., 1980. A new Haptoglossa attacking rotifers by rapid injection with an infective sporidium. Mycologia, 72: 1186-1194.

Barron, G.L., 1987. The gun cell of Haptoglossa mirabilis. Mycologia, 79: 877-883.

Barron, G.L., 1989. Host range studies for Haptoglossa and a new species, Haptoglossa intermedia. Canadian Journal of Botany, 67: 1645-1648.

Barron, G.L., 1990. A new and unusual species of Haptoglossa. Canadian Journal of Botany, 68: 435-438.

Bartnicki-Garcia S., 1968. Cell wall chemistry, morphogenesis, and taxonomy of fungi. Annual Review of Microbiology, 22: $87-108$.

Bates, S.S., K.A. Hubbard, N. Lundholm, M. Montresor \& C.P. Leaw, 2018. Pseudo-nitzschia, Nitzschia, and domoic acid: New research since 2011. Harmful Algae, 79: 3-43.

Baweja P., S. Kumar, D. Sahoo \& I. Levine, 2016. Biology of Seaweeds. In: Fleurence, J. \& I. Levine, (eds.), Seaweed in Health and Disease Prevention, Academic Press, Cambridge, Massachusetts, pp. 41-106.

Beakes, G.W. \& S.L. Glockling, 1998. Injection tube differentiation in gun cells of a Haptoglossa species which infects nematodes. Fungal Genetics and Biology, 24: 4568.

Beakes, G.W. \& S.L. Glockling, 2000. An ultrastructural analysis of organelle arrangement during gun (infection) cell differentiation in the nematode parasite Haptoglossa dickii. Mycological Research, 104: 1258-1269.

Beakes, G.W. \& S.L. Glockling, 2002. A comparative finestructural study of dimorphic infection cells in the nematophagous parasite Haptoglossa erumpens. Fungal Genetics and Biology, 37: 250-262.

Beakes, G.W., S.L. Glockling \& S.S. Sekimoto, 2012. The evolutionary phylogeny of the oomycete "fungi". Protoplasma, 249: 3-19.

Beakes, G.W. \& S. Sekimoto, 2009. The evolutionary phylogeny of oomycetes-insights gained from studies of holocarpic parasites of algae and invertebrates. In: Lamour
K. \& S. Kamoun, (eds.), Oomycete Genetics and Genomics: Diversity, Interactions and Research Tools. Wiley, New York, pp. 1-24.

Beakes, G.W. \& M. Thines, 2017. Hyphochytriomycota and Oomycota. In: Archibald J.M., A.G.B. Simpson \& C.H. Slamovits, (eds.), Handbook of the Protists. Springer, Germany.

Bortnick, R.N., M.J. Powell, \& T.N. Bangert, 1985. Zoospore fine-structure of the parasite Olpidiopsis saprolegniae (Oomycetes, Lagenidiales). Mycologia, 77: 861-879.

Buaya, A.T., S. Ploch, L. Hanic, B. Nam, L. Nigrelli, A. Kraberg \& M. Thines, 2017. Phylogeny of Miracula helgolandica gen. et sp. nov. and Olpidiopsis drebesii sp. nov. two basal oomycete parasitoids of marine diatoms, with notes on the taxonomy of Ectrogella-like species. Mycological Progress, 16: 1041-1050.

Buaya, A.T., S. Ploch \& M. Thines, 2019a. Rediscovery and phylogenetic placement of Olpidiopsis gillii (de Wildeman) Friedmann, a holocarpic oomycete parasitoid of freshwater diatoms. Mycoscience, 60: 141-146.

Buaya, A.T. \& M. Thines, 2019b. Miracula moenusica, a new member of the holocarpic parasitoid genus from the invasive freshwater diatom Pleurosira laevis. Fungal Systematics and Evolution, 3: 19-33.

Buaya, A.T., A. Kraberg \& M. Thines, 2019c. Dual culture of the oomycete Lagenisma coscinodisci Drebes and Coscinodiscus diatoms as a model for plankton/parasite interactions. Helgoland Marine Research, 73: 92.

Buaya, A.T. S. Ploch, S. Inaba \& M. Thines, 2019d. Holocarpic oomycetes parasitoids of red algae are not Olpidiopsis. Fungal Systematics and Evolution, 4: 21-31.

Buaya, A.T. \& M. Thines, 2020a. Diatomophthoraceae-a new family of olpidiopsis-like diatom parasitoids largely unrelated to Ectrogella. Fungal Systematics and Evolution, 5: 113-118.

Buaya, A.T. \& M. Thines, 2020b. Bolbea parasitica gen. et sp. nov., a cultivable holocarpic parasitoid of the earlydiverging Saprolegniomycetes. Fungal Systematics and Evolution, 6: 129-137.

Buaya, A.T., S. Ploch, A. Kraberg \& M. Thines, 2020c. Phylogeny and cultivation of the holocarpic oomycete Diatomophthora perforans comb. nov., an endoparasitoid of marine diatoms. Mycological Progress, 19:441-454.

Butler E.J., 1907. An account of the genus Pythium and some Chytridiaceae. Memoirs of the Department of Agriculture in India. Botanical Series, 1: 1-160.

Canter, H.M., 1949. On Aphanomycopsis bacillariacearum scherffel, A. desmidiella n.sp., and Ancylistes spp. in Great Britain. Transactions of the British Mycological Society, 32: 
162-170.

Canter, H.M., 1950. Studies on British chytrids: IX. Anisolpidium stigeoclonii (de Wildeman) n. comb. Transactions of the British Mycological Society, 33: 335344.

Cavalier-Smith, T., 1997. Sagenista and bigyra, two phyla of heterotrophic heterokont chromists. Archiv für Protistenkunde, 148: 253-267.

Cavalier-Smith, T., 2018. Kingdom Chromista and its eight phyla: a new synthesis emphasising periplastid protein targeting, cytoskeletal and periplastid evolution, and ancient divergence. Protoplasma, 255: 297-357.

Cavalier-Smith. T. \& E.E.Y. Chao, 2006. Phylogeny and megasystematics of phagotrophic heterokonts (Kingdom Chromista). Journal of Molecular Evolution, 62: 388-420.

Choi, Y.J., G.W. Beakes, S. Glockling, J.M. Kruse, B. Nam, L. Nigrelli, S. Ploch, H.D. Shin, R.G. Shivas, S. Telle, H. Voglmayr \& M. Thines, 2015. Towards a universal barcode of oomycetes--a comparison of the cox 1 and cox2 loci. Molecular Ecology Resources, 15: 1275-1288.

Chukanhom, K., L.V. Khoa, K. Hatai \& P. Borisutpeth, 2003. Haliphthoros milfordensis isolated from black tiger prawn larvae (Penaeus monodon) in Vietnam. Mycoscience, 44: 123-127.

Coker, W.C., 1923. The Saprolegniaceae, with Notes on Other Water Molds. University of North Carolina Press, Chapel Hill. 444 pp.

Cooper, B.A. \& J.M. Aronson, 1967. Cell wall structure of Pythium debaryanum. Mycologia, 59: 658-70.

Cornu, M., 1872. Monographie des Saprolegniees, etude physiologique et systematique. Annales des Sciences Naturelles Botanique, 15: 1-198.

Couch, J.N., 1935. New or little known Chytridiales. Mycologia, 27: 160-175.

de Wildeman, E., 1895. Notes mycologiques IV. Annales de la Societe de Belge Microscopie, 19: 59-80.

de Wildeman, E., 1896. Notes mycologiques. Annales de la Societe de Belge Microscopie, 20: 21-64.

Derevnina, L., B. Petre, R. Kellner, Y.F. Dagdas, M.N. Sarowar, A. Giannakopoulou, A.C. De la Concepcion, A. Chaparro-Garcia, H.G. Pennington, P. van West \& S. Kamoun, 2016. Emerging oomycete threats to plants and animals. Philisophical Transactions of the Royal Society B, 371: 20150459.

Dick, M.W., 2001. Straminipilous Fungi. Kluwer, Netherlands. $670 \mathrm{pp}$.

Ding, H.Y. \& J.H. Ma, 2005. Simultaneous infection by red rot and chytrid diseases in Porphyra yezoensis Ueda. Journal of Applied Phycology, 17: 51-56.
Drebes, G., 1966. Ein parasitischer Phycomycet (Lagenidiales) in Coscinodiscus. Helgolander Wissenschaftliche Meeresuntersuchungen, 13:426-435.

Drechsler, C.E., 1940. Three fungi destructive to free-living terricolous nematodes. Journal of the Washington Academy of Sciences, 30: 240-254.

Duffy, M.A., T.Y. James, \& A. Longworth, 2015. Ecology, virulence, and phylogeny of Blastulidium paedophthorum, a widespread brood parasite of Daphnia spp. Applied and Environmental Microbiology, 81: 5486-5496.

Emerson, R. \& A.A. Held, 1969. Aqualinderella fermentans gen. et sp. n., a phycomycete adapted to stagnant waters. II. isolation, cultural characteristics, and gas relations. American Journal of Botany, 56: 1103-1120.

Emerson, R. \& D.O. Natvig, 1981. Adaptation of fungi to stagnant waters. In: Wicklow, D.T. \& G.C. Carroll (eds.) The Fungal Community. Its Organisation and Role in the Ecosystem. Marcel Dekker, New York, pp. 109-128.

Emerson, R. \& W.H. Weston, 1967. Aqualinderella fermentans gen. et sp. nov., a phycomycete adapted to stagnant waters. I. morphology and occurrence in nature. American Journal of Botany, 54: 702-719.

Fawke, S., M. Doumane \& S. Schornack, 2015. Oomycete interactions with plants: Infection strategies and resistance principles. Microbiology and Molecular Biology Reviews, 79: 263-280.

Feldmann J. \& G. Feldmann, 1955. Observations sur quelques Phycomycetes marins nouveaux où peu connus. Revue Mycologique 20: 231-251.

Fischer, A., 1882. Untersuchungen fiber die Parasiten der Saprolegnieen. Jahrbiicher für wissenschoftliche Botanik, 13: 286-371.

Fisher, W.H., E.H. Nilson \& R.A. Shleser, 1975. Effect of the fungus Haliphthoros milfordensis on the juvenile stages of the American lobster Homarus americanus. Journal of Invertebrate Pathology, 26: 41-45.

Fletcher, K., A. Žuljević, A. Tsirigoti, B. Antolić, C. Katsaros, V. Nikolić, P. van West \& F.C. Küpper, 2015. New record and phylogenetic affinities of the oomycete Olpidiopsis feldmanni infecting Asparagopsis sp. (Rhodophyta). Diseases of Aquatic Organisms, 117: 45-57.

Friedmann, I., 1952. Über neue und wenig bekannte auf Diatomeen parasitierende Phycomyceten. Österreichische Botanische Zeitschrift, 99: 173-219.

Gachon, C.M.M., M. Strittmatter, Y. Badis, K.I. Fletcher, P. van West \& D.G. Müller, 2017. Pathogens of brown algae: culture studies of Anisolpidium ectocarpii and $A$. rosenvingei reveal that the Anisolpidiales are uniflagellated oomycetes. European Journal of Phycology, 52: 133-148. 
Gachon, C.M.M., M. Strittmatter, J. Kleinteich, D.G. Müller \& F.C. Kupper, 2009. Detection of differential host susceptibility to the marine oomycete pathogen Eurychasma dicksonii by Real-Time PCR: not all algae are equal. Applied and Environmental Microbiology, 75: 322328.

Garvetto, A., E. Nézan, Y. Badis, G. Bilien, P. Arce, E. Bresnan, C.M.M. Gachon \& R. Siano, 2018. Novel widespread marine Oomycetes parasitising diatoms, including the toxic genus Pseudo-nitzschia: Genetic, morphological, and ecological characterisation. Frontiers in Microbiology, 9: 2918.

Garvetto, A., M.-M. Perrineau, M. Dressler-Allame, E. Bresnan \& C.M.M. Gachon, 2019. "Ectrogella" parasitoids of the diatom Licmophora sp. are polyphyletic. Journal of Eukaryotic Microbiology, 67: 18-27.

Gherardi, F., 2007. Biological invaders in inland waters: Profiles, distribution, and threats. Nature Springer, Netherlands. 734 pp.

Gill, C.H., 1893. On an endophytic parasite of diatoms. Journal of Royal Microscopical Society London, 1: 1-4.

Glockling, S.L. \& G.W. Beakes, 2000a. Two new Haptoglossa species (H. erumpens and $H$. dickii) infecting nematodes in cow manure. Mycological Research, 104: 100-106.

Glockling, S.L. \& G.W. Beakes, 2000b. The ultrastructure of the dimorphic infection cells of Haptoglossa heteromorpha illustrates the developmental plasticity of infection apparatus structures in a nematode parasite. Canadian Journal of Botany, 78: 1095-1107.

Glockling, S.L. \& G.W. Beakes, 2001. Two new species of Haptoglossa from N.E. England, H. northumbrica and $H$. polymorpha. Botanical Journal of the Linnean Society, 136: 329-338.

Glockling, S.L. \& G.W. Beakes, 2002. Ultrastructural morphogenesis of dimorphic arcuate infection (gun) cells of Haptoglossa erumpens an obligate parasite of Bunonema nematodes. Fungal Genetics and Biology, 37: 250-62.

Glockling, S.L. \& L.C. Serpell, 2010. A new species of aplanosporic Haptoglossa, H. beakesii, with vesiculate spore release. Botany, 88: 93-101.

Gotelli, D., 1971. Lagenisma coscinodisci, a parasite of the marine diatom Coscinodiscus occurring in the Puget Sound, Washington. Mycologia, 63: 171-174.

Grahame, E.S., 1976. The occurrence of Lagenisma coscinodisci in Palmeria hardmaniana from Kingston harbour, Jamaica. British Phycological Society, 11: 57-61.

Grenville-Brigg, L., C.M.M. Gachon, M. Strittmatter, L. Sterck, F.C. Küpper \& P. van West, 2011. A molecular insight into algal-oomycete warfare: cDNA analysis of Ectocarpus siliculosus infected with the basal oomycete Eurychasma dicksonii. PLoS ONE, 6: e24500.

Hakariya, M., D. Hirose. \& S. Tokumasu, 2007. A molecular phylogeny of Haptoglossa species, terrestrial peronosporomycetes (oomycetes) endoparasitic on nematodes. Mycoscience, 48: 169-175.

Hanic, L.A., S. Sekimoto \& S.S. Bates, 2009. Oomycete and chytrid infections of the marine diatom Pseudo-nitzschia pungens (Bacillariophyceae) from Prince Edward Island, Canada. Canadian Journal of Botany, 87: 1096-1105.

Hassett, B.T, M. Thines, A.T. Buaya, S. Ploch \& R. Gradinger, 2019. A glimpse into the biogeography, seasonality, and ecological functions of arctic marine Oomycota. IMA Fungus, 10: 6.

Hatai, K., 2012. Disease of Fish and Shellfish Caused by Marine Fungi. In: Raghukumar, C., (ed.), Biology of Marine Fungi. Springer Nature, Switzerland AG. pp. 15-52.

Hatai, K., B. Bian, M.C.L. Baticados \& S. Egusa, 1980. Studies on fungal diseases in crustaceans: II. Haliphthoros philippinensis sp. novo isolated from cultivated larvae of the jumbo tiger prawn (Penaeus monodon). Transactions of the Mycological Society of Japan, 21: 47-55.

Hatai, K., D. Roza \& T. Nakayama, 2000. Identification of lower fungi isolated from larvae of mangrove crab Scylla serrata, in Indonesia. Mycoscience, 41: 565-572.

Hatcher, M.J., J.T.A. Dick \& A.M. Dunn, 2012. Disease emergence and invasions. Functional Ecology, 26: 12751287.

Hudspeth, D.S.S., S.A. Nadler \& M.E.S. Hudspeth, 2000. A cox II molecular phylogeny of the Peronosporomycetes. Mycologia, 92: 674-684.

Hulvey, J.P., S. Telle, L. Nigrelli, K. Lamour \& M. Thines, 2010. Salisapiliaceae-A new family of oomycetes from marsh grasss litter of southeastern North America. Persoonia, 25: 109-116.

Johnson, T.W., 1966. A Lagenidium in the marine diatom Coscinodiscus centralis. Mycologia, 58: 131-135.

Kagami M., T. Miki \& G. Takimoto, 2014. Mycoloop: chytrids in aquatic food webs. Frontiers in Microbiology, 5: 166.

Kamoun, S., 2003. Molecular genetics of pathogenic oomycetes. Eukaryotic Cell, 2: 191-199.

Kamoun, S., O. Furzer, J.D.G. Jones, H.S. Judelson, G.S. Ali, R.J.D. Dalio, S.G. Roy, L. Schena, A. Zambounis, F. Panabières, D. Cahill, M. Ruocco, A. Figueiredo, X.R. Chen, J. Hulvey, R. Stam, K. Lamour, M. Gijzen, B. M. Tyler, N.J. Grünwald, M.S. Shahid, D.F.A. Tomé, M. Tör, G. van Den Ackerveken, J. McDowell, F. Daayf, W.E. Fry, H. Lindqvist-Kreuze, H.J.G. Meijer, J. Petre, J. Ristaino, K. Yoshida, P.R.J. Birch \& F. Govers, 2015. The top 10 
oomycete pathogens in molecular plant pathology. Molecular Plant Pathology, 16: 413-434.

Karling, J.S., 1942. The simple holocarpic bifiagellate Phycomycetes. Karling JS, New York, USA.

Karling, J.S., 1943. The life history of Anisolpidium ectocarpii gen. nov. et sp. nov., and a synopsis and classification of other fungi with anteriorly uniflagellate zoospores. American Journal of Botany, 30: 637-648.

Karling, J.S., 1968. Zoosporic fungi of Oceania. I. Journal of the Elisha Mitchell Scientific Society, 84: 166-178.

Karling, J.S., 1977. Some zoosporic fungi of Florida. Nova Hedwigia, 28: 209-229.

Karling, J.S., 1981. Predominantly holocarpic and eucarpic simple biflagellate phycomycetes

(2nd ed.). J. Cramer, Vaduz. 252 pp.

Kawamura, Y., K. Yokoo, M. Tojo \& M. Hishiike, 2005. Distribution of Pythium porphyrae, the causal agent of red rot disease of Porphyra spp., in the Ariake Sea, Japan. Plant Disease, 89: 1041-1047.

Kitancharoen, N. \& K. Hatai, 1995. A marine oomycete Atkinsiella panulirata sp. nov. from philozoma of spiny lobster, Panulirus japonicus. Mycoscience, 36: 97-104.

Klochkova, T.A. J.B. Shim, M.S. Hwang \& G.H. Kim, 2012. Host-parasite interactions and host species susceptibility of the marine oomycete parasite, Olpidiopsis sp., from Korea that infects red algae. Journal of Applied Phycology, 24: 135-144.

Klochkova, T.A., Y. Shin, K.H. Moon, T. Motomura \& G. Kim, 2016. New species of unicellular obligate parasite, Olpidiopsis pyropiae sp. nov. that plagues Pyropia sea farms in Korea. Journal of Applied Phycology, 27: 73-83.

Klochkova, T.A., M.S. Kwak \& G.H. Kim, 2017. A new endoparasite Olpidiopsis heterosiphoniae sp. nov. that infects red algae in Korea. Algal Research, 28: 264-269.

Kühn, S.F., L.K. Medlin \& G. Eller, 2004. Phylogenetic position of the parasitoid nanoflagellate Pirsonia inferred from nuclear-encoded small subunit ribosomal DNA and a description of Pseudopirsonia n. gen. and Pseudopirsonia mucosa (Drebes) comb. nov. Protist, 155: 143-156.

Küpper, F.C., I. Maier, D.G. Müller, S. Loiseaux-de Goer \& L. Guillou, 2006. Phylogenetic affinities of two eukaryotic pathogens of marine macroalgae, Eurychasma dicksonii (Wright) Magnus and Chytridium polysiphoniae Cohn. Cryptogamie Algologie, 27: 165-184.

Kwak, M.S., T.A. Klochkova, S. Jeong \& G.H. Kim, 2017. Olpidiopsis porphyrae var. koreanae, an endemic endoparasite infecting cultivated Pyropia yezoensis in Korea. Journal of Applied Phycology, 29: 2003-2012.

Lafferty K. D., S. Allesina, M. Arim, C.J. Briggs, G. De Leo,
A.P. Dobson, J.A. Dunne, P.T. J. Johnson, A.M. Kuris, D.J. Marcogliese, N.D. Martinez, J. Memmott, P.A. Marquet, J.P. McLaughlin, E.A. Mordecai, M. Pascual, R. Poulin \& D.W. Thieltges, 2008. Parasites in food webs: the ultimate missing links. Ecology Letters, 11: 533-546.

Lamour, K. \& S. Kamoun, eds. 2009. Oomycete Genetics and Genomics: Diversity, Interactions and Research Tools. John Wiley \& Sons, Hoboken, New Jersey. 574 pp.

Lara, E. \& L. Belbahri, 2011. SSU rRNA reveals major trends in oomycete evolution. Fungal Diversity, 49: 93-100.

Leaño, E., 2002. Haliphthoros spp. from spawned eggs of captive mud crab, Scylla serrata, broodstocks. Fungal Diversity, 9: 93-103.

Lee, Y.N., K. Hatai and O. Kurata 2017. Haliphthoros sabahensis sp. nov. isolated from mud crab Scylla tranquebarica eggs and larvae in Malaysia. Fish Pathology, 52: 31-37.

Lee, D.L., P.C. Vaughan \& U. Durschner-Pelz, 1992. Ultrastructure of the thallus and secondary spore of the nematophagous fungus Haptoglossa heterospora (Oomycetes). Journal of Invertebrate Pathology, 59: 33-39.

Lelong, A., H. Hegaret, P. Soudant \& S. Bates, 2012. Pseudonitzschia (Bacillariophyceae) species, domoic acid and amnesic shellfish poisoning: revisiting previous paradigms. Phycologia, 51: 168-216.

Lévesque, C.A., 2011. Fifty years of oomycetes-from consolidation to evolutionary and genomic exploration. Fungal Diversity, 50: 35-46.

Li, W., T. Zhang, X. Tang \& B. Wang, 2010. Oomycetes and fungi: important parasites on marine algae. Acta Oceanologica Sinica, 29: 74-81.

Lin, C.C. \& J.M. Aronson, 1970. Chitin and cellulose in the cell walls of the oomycete, Apodachlya sp. Archiv für Mikrobiologie, 72: 111-114.

Magnus, P., 1905. Über die Gattung, zu der Rhizophydium dicksonii Wright gehört. Hedwigia, 44: 347-349.

Marano, A.V., A.L. Jesus, J.I. de Souza, G.H. Jeronimo, D.R. Gonçalves, M.C. Boro, S.C.O. Rocha \& C.L.A. PiresZottarelli, 2016. Ecological roles of saprotrophic Peronosporales (Oomycetes, Straminipila) in natural environments. Fungal Ecology, 19: 77-88.

Massan, R., J. Castresana, V. Balague, L. Guillou, K. Romari, A. Groisillier, K. Valentin \& C. Pedro-Alio, 2004. Phylogenetic and ecological analysis of novel marine stramenopiles. Applied and Environmental Microbiology, 70: 3528-3534.

Massana, R., R. Terrado, I. Forn, C. Lovejoy \& C. Pedro-Alio, 2006. Distribution and abundance of uncultured heterotrophic flagellates in the world oceans. Environmental 
Microbiology, 8: 1515-1522.

Maurizio, A.,1895. Zur Kenntniss der schweizerischen Wasserpilze nebst Angaben über eine neue Chytridinee. Jahresbericht Naturforchung Gessellchaft Graubündens Chur, 38: 9-38.

McLarty, D.A., 1941. Studies in the family Woroninaceae-I. Discussion of a new species including consideration of the genera Pseudolpidium and Olpidiopsis. Bulletin of the Torrey Botanical Club, 68: 49-66.

Miller, C.E., 1962. A new species of Petersenia parasitic on Pythium. Mycologia, 54: 422-431.

Moon-van der Staay, S.Y., R. De Wachter \& D. Vaulot, 2001. Oceanic 18S rDNA sequences from picoplankton reveal unsuspected eukaryotic diversity. Nature, 409: 607-610.

Müller, D.G., C.M.M. Gachon \& F.C. Küpper, 2008. Axenic clonal cultures of filamentous brown algae: Initiation and maintenance. Cahiers de Biologie Marine, 49: 59-65.

Müller, D.G., F.C. Küpper \& H. Küpper, 1999. Infection experiments reveal broad host ranges of Eurychasma dicksonii (Oomycota) and Chytridium polysiphoniae (Chytridiomycota), two eukaryotic parasites of marine brown algae (Phaeophyceae). Phycological Research, 47: 217-223.

Muraosa, Y., K. Morimoto, A. Sano, K. Nishimura \& K. Hatai, 2009. A new peronosporomycete, Halioticida noduliformans gen. et sp. nov., isolated from white nodules in the abalone Haliotis spp. from Japan. Mycoscience, 50: 106-115.

Myklestad, S.M. \& E. Granum, 2009. Biology of $(1,3)-\beta-$ Glucans and Related Glucans in Protozoans and Chromistans. In: Bacic, A., G. Fincher \& B. Stone, (eds.), Chemistry, Biochemistry, and Biology of 1-3 Beta Glucans and Related Polysaccharides, Academic Press, New York. pp. 353-38.

Nakamura, K. \& K. Hatai, 1995. Atkinsiella dubia and its related species. Mycoscience, 36: 431-438.

Park, C.S. \& E.K. Hwang, 2015. Biochemical characterisation of Pyropia yezoensis-AP1 strain accompanies the resistance reaction to the red rot disease pathogen, Pythium porphyrae. Journal of Applied Phycology, 27: 2149-2156.

Park, C.S., M. Kakinuma \& H. Amano, 2006. Forecasting infections of the red rot disease on Porphyra yezoensis Ueda (Rhodophyta) cultivation farms. Journal of Applied Phycology, 18: 295-299.

Parson, T.R., 1962. Infection of a marine diatom by Lagenidium sp. Canadian Journal of Botany, 40: 523.

Pereira, R. \& C. Yarish, 2008. Mass Production of Marine Macroalgae. In: Jørgensen, S.E. \& B.D. Faith, (eds.), Encyclopedia of Ecology, Elsevier, Oxford. pp. 2236-2247
Petersen, H.E., 1905. Contributions a la connaissance des Phycomycetes marins (Chytridineae Fischer). Oversigt over det Kongelige Danske videnskabernes selskabs forhandlinger, 5: 439-188.

Pueschel, C.M. and J.P. van der Meer, 1985. Ultrastructure of the fungus Petersenia palmariae (Oomycetes) parasitic on the alga Palmaria mollis (Rhodophyceae). Canadian Journal of Botany, 63: 409-418.

Raghukumar, C., 1980. An ultrastructural study of the marine diatom Licmophora hyalina and its parasite Ectrogella perforans. I. Infection of host cells. Canadian Journal of Botany, 58: 1280-1290.

Raghukumar, C., 1987. Fungal parasites of marine algae from Mandapam (South India). Diseases of Aquatic Organisms, 3: $137-145$.

Raghukumar, C., 2009. Fungal parasites of the marine green algae, Cladophora and Rhizoclonium. Botanica Marina, 29: 289-297.

Scherffel, A., 1925. Endophytische Phycomyceten-Parasiten der Bacillariaceen und einige neue Monadinen. Ein Beitrag zur Phylogenie der Oomyceten (Schroter). Archiv für Protistenkunde, 52: 1-141.

Scheler, B., V. Schnepf, C. Galgenmüller, S. Ranf, \& R. Hückelhoven, 2016. Barley disease susceptibility factor RACB acts in epidermal cell polarity and positioning of the nucleus. Journal of Experimental Botany, 67: 3263-3275.

Schnepf, E. \& G. Drebes, 1977. Über die Entwicklung des marinen parasitischen Phycomyceten Lagenisma coscinodisci (Lagenidiales). Helgoländer Wissenschaftlische Meeresuntersuchungen, 29: 291-301.

Schnepf, E. \& J. Heinzmann, 1980. Nuclear movement, tip growth and colchicine effects in Lagenisma coscinodisci Drebes (Oomycetes, Lagenidiales). Biochem. Physiol. Pflanzen, 175: 67-76.

Schnepf, E., G. Deichgräber \& G. Drebes, 1978a. Development and ultrastructure of the marine parasitic oomycete Lagenisma coscinodisci Drebes (Lagenidiales): Thallus, zoosporangium, mitosis and meiosis. Archives of Microbiology, 116: 121-132.

Schnepf, E., G. Deichgräber \& G. Drebes, 1978b. Development and ultrastructure of the marine, parasitic oomycete, Lagenisma coscinodisci Drebes (Lagenidiales). The infection. Archives of Microbiology, 116: 133-139.

Schnepf, E., G. Deichgräber \& G. Drebes, 1978c. Development and ultrastructure of the marine, parasitic oomycete, Lagenisma coscinodisci Drebes (Lagenidiales): Formation of the primary zoospores and their release. Protoplasma, 94: 263-280.

Scholz, B., F.C. Küpper, W. Vyverman \& U. Karsten, 2015. 
Effects of eukaryotic pathogens (Chytridiomycota and Oomycota) on marine benthic diatom communities in the Solthörn tidal flat (southern North Sea, Germany). European Journal of Phycology, 51: 1-17.

Sekimoto, S., G.W. Beakes, C.M.M. Gachon, D.G. Müller, F.C. Küpper \& D. Honda, 2008a. The development, ultrastructural cytology, and molecular phylogeny of the basal oomycete Eurychasma dicksonii, infecting the filamentous phaeophyte algae Ectocarpus siliculosus and Pylaiella littoralis. Protist, 159: 299-318.

Sekimoto, S., K. Yokoo, Y. Kawamura \& D. Honda, 2008b. Taxonomy, molecular phylogeny, and ultrastructural morphology of Olpidiopsis porphyrae sp. nov. (Oomycetes, stramenopiles), a unicellular obligate endoparasite of Porphyra spp. (Bangiales, Rhodophyta). Mycological Research, 112: 361-374.

Sekimoto, S., T.A. Kochkova, J.A. West, G.W. Beakes \& D. Honda, 2009. Olpidiopsis bostychiae: A new species endoparasitic oomycete that infects Bostrychia and other red algae. Phycologia, 48: 460-472.

Sekimoto, S., K. Hatai \& D. Honda, 2007. Molecular phylogeny of an unidentified Haliphthoros-like marine oomycete and Haliphthoros milfordensis inferred from nuclear encoded small and large subunit rDNA genes and mitochondrialencoded cox2 gene. Mycoscience, 48: 212-221.

Shanor, L., 1939. Studies in the genus Olpidiopsis. II. The relationship of Pseudolpidium Fischer and Olpidiopsis (Cornu) Fischer. Journal of the Elisha Mitchell Scientific Society, 55: 179-195.

Shanor, L., 1940. Studies in the genus Olpidiopsis. III. Some observations on the host range of certain species. Journal of the Elisha Mitchell Scientific Society, 56: 165-176.

Silberfeld, T., F. Rousseau \& B. de Reviers, 2014. An updated classification of brown algae (Ochrophyta, Phaeophyceae). Cryptogamie Algologie, 35: 117-156.

Skovgaard, A., 2014. Dirty tricks in the plankton: Diversity and role of marine parasitic protists. Acta Protozoologica, 53: 51-62.

Sparrow, F.K., 1960. Aquatic Phycomycetes, The University of Michigan Press, Ann Arbor, USA.

Sparrow, F.K., 1934. Observations on marine Phycomycetes collected in Denmark. Dansk Bot. Ark., 8:1-24.

Sparrow, F.K., 1936. Biological observations on the marine fungi of Woods Hole waters. Biological Bulletin, 70:236263.

Sparrow, F.K., 1943. The aquatic Phycomycetes, exclusive of the Saproiegniaceae and Pythium. University of Michigan Press, Ann Arbor. 1187 pp.

Sparrow, F.K. 1976. The present status of classification in biflagellate fungi, In: Jones, E.B.G., (ed.), Recent Advances in Aquatic Mycology. Wiley, New York. pp. 213-222.

Sparrow, F.K. \& B. Ellison, 1949. Olpidiopsis schenkiana and its hyperparasite Ectrogella besseyi n. sp. Mycologia, 41: 28 -35 .

Strittmatter, M., C.M.M. Gachon \& F.C. Küpper, 2009. Ecology of Lower Oomycetes, In: Lamour, K., \& S. Kamoun, (eds,), Oomycete Genetics and Genomics: Diversity, Interactions, and Research Tools. John Wiley \& Sons, Hoboken, New Jersey. pp. 1-24.

Strittmatter, M., C.M.M. Gachon, D.G. Müller, J. Kleinteich, S. Heesch, A. Tsirigoti, C. Katsaros, M. Kostopoulou \& F.C. Küpper, 2013. New records of intracellular eukaryotic pathogens challenging brown macroalgae in the East Mediterranean Sea, with emphasis on LSU rRNA data of the oomycete pathogen Eurychasma dicksonii. Diseases of Aquatic Organisms, 104: 1-11.

Strittmatter, M., L.J. Grenville-Briggs, L. Breithut, P. van West, C.M.M. Gachon \& F.C. Küpper, 2016. Infection of the brown alga Ectocarpus siliculosus by the oomycete Eurychasma dicksonii induces oxidative stress and halogen metabolism. Plant, Cell and Evironment, 39: 259-271.

Tharp, T.P. \& C.E. Bland, 1977. Biology and host range of Haliphthoros milfordensis Vishniac. Canadian Journal of Botany, 55: 2936-2944.

Thines, M., 2014. Phylogeny and evolution of plant pathogenic oomycetes-a global overview. European Journal of Plant Pathology, 138: 431-447.

Thines, M., 2019. An evolutionary framework for host shiftsjumping ships for survival. New Phytologist, 224: 605-617.

Thines, M. \& Y.-J. Choi, 2016. Evolution, diversity, and taxonomy of the Peronosporaceae, with focus on the genus Peronospora. Phytopathology, 106: 6-18.

Thines, M., B. Nam, L. Nigrelli, G.W. Beakes \& A. Kraberg, 2015. The diatom parasite Lagenisma coscinodisci (Lagenismatales, Oomycota) is an early diverging lineage of the Saprolegniomycetes. Mycological Progess, 14: 75.

Thines, M. \& O. Spring, 2005. A revision of Albugo (Chromista, Peronosporomycetes). Mycotaxon, 92: 443-458.

Tokunaga, Y., 1933. Studies on the aquatic chytrids of Japan. II. Olpidiaceae. Transactions of the Sapporo Natural History Society, 12: 119-123.

Tong, S.M., 1995. Developayella elegans nov. gen., nov. spec., a new type of heterotrophic flagellate from marine plankton. European Journal of Protistology, 31: 24-31.

Trainer, V.L., S.S. Bates, N. Lundholm, A.E. Thessen, W.P. Cochlan, N.G. Adams \& C.G. Trick, 2012. Pseudonitzschia physiological ecology, phylogeny, toxicity, monitoring and impacts on ecosystem health. Harmful 
Algae, 14: 271-300.

Traquair, J.A. and W.E. McKeen, 1980. Electron microscopy of developing Aphanomyces oogonia and oospore. Mycologia, 72: 378-394.

Tsirigoti, A., G.W. Beakes, C. Hervé, C.M.M. Gachon \& C. Katsaros, 2015. Attachment, penetration and early host defense mechanisms during the infection of filamentous brown algae by Eurychasma dicksonii. Protist, 252: 84556.

Tsirigoti, A., F.C. Küpper, C.M.M. Gachon \& C. Katsaros, 2013. Filamentous brown algae infected by the marine, holocarpic oomycete Eurychasma dicksonii: first results on the organisation and the role of cytoskeleton in both host and parasite. Plant Signaling and Behavior, 8: 11, e26367.

Vishniac, H.S., 1958. A new marine phycomycete. Mycologia, 50: 66-79.

Vogel, H.J., 1960. Two modes of lysine synthesis among the lower fungi: evolutionary significance. Biochimica et Biophysica Acta, 41: 172-173.

Vogel, H.J., 1961. Lysine synthesis and phytogeny of lower fungi: Some chytrids versus Hyphochytrium. Nature, 189: 1026-1027.

Vogel, H.J., 1964. Distribution of lysine pathways among fungi: Evolutionary implications. The American Naturalist, 98: 435-446.

Walker, C.A. \& P. van West, 2007. Zoospore development in the oomycetes. Fungal Biology Reviews, 21: 10-18.

Wang, M.C. \& S. Bartnicki-Garcia, 1974. Mycolaminarans: Storage (1-3)- $\beta$-D-glucans from the cytoplasm of the fungus Phytophthora palmivora. Carbohydrate Research, 37: 331338.

Wetsteyn, L.P. \& L. Peperzak, 1991. Field observations in the Oosterschelde (the Netherlands) on Coscinodiscus concinnus and Coscinodiscus granii (Bacillariophyceae) infected by the marine fungus Lagenisma coscinodisci (Oomycetes). Hydrobiological Bulletin, 25: 15-21.

Whiffen, A.J., 1942. A discussion of some species of Olpidiopsis and Pseudolpidium. American Journal of Botany, 29: 607-611.

Wijayawardene, N.N., K.D. Hyde, L.K.T. Al-Ani., et al., 2020. Outline of Fungi and fungus-like taxa. Mycosphere, 11: 1060-1456.

Zopf, W., 1884. Zur Kenntniss der Phycomyceten. I. Zur Morphologie und Biologie der Ancylisteen und Chytridiaceen. Nova Acta Academiae Caesareae Leopoldino-Carolinae Germanicae Naturae Curiosorum, 47: 143-236. 